University of Massachusetts Amherst

ScholarWorks@UMass Amherst

March 2016

\title{
Oceanic Anoxia Event 2 ( 94 Ma) in the U.S. Western Interior Sea: High Resolution Foraminiferal Record of the Development of Anoxia in a Shallow Epicontinental Sea
}

Amanda L. Parker

University of Massachusetts Amherst

Follow this and additional works at: https://scholarworks.umass.edu/masters_theses_2

Part of the Geology Commons, and the Paleontology Commons

\section{Recommended Citation}

Parker, Amanda L., "Oceanic Anoxia Event 2 ( 94 Ma) in the U.S. Western Interior Sea: High Resolution Foraminiferal Record of the Development of Anoxia in a Shallow Epicontinental Sea" (2016). Masters Theses. 331.

https://doi.org/10.7275/7948196 https://scholarworks.umass.edu/masters_theses_2/331

This Open Access Thesis is brought to you for free and open access by the Dissertations and Theses at ScholarWorks@UMass Amherst. It has been accepted for inclusion in Masters Theses by an authorized administrator of ScholarWorks@UMass Amherst. For more information, please contact scholarworks@library.umass.edu. 
OCEANIC ANOXIA EVENT 2 ( 94 MA) IN THE U.S. WESTERN INTERIOR SEA: HIGH RESOLUTION FORAMINIFERAL RECORD OF THE DEVELOPMENT OF ANOXIA IN A SHALLOW EPICONTINENTAL SEA

\author{
A Thesis Presented
}

by

\begin{abstract}
AMANDA L. PARKER
Submitted to the Graduate School of the

University of Massachusetts Amherst in partial fulfillment

of the requirements for the degree of
\end{abstract}

MASTER OF SCIENCE

February 2016

Geosciences 
OCEANIC ANOXIA EVENT 2 ( 94 MA) IN THE U.S. WESTERN INTERIOR SEA: HIGH RESOLUTION FORAMINIFERAL RECORD OF THE DEVELOPMENT OF ANOXIA IN A SHALLOW EPICONTINENTAL SEA

A Thesis Presented

by

AMANDA L. PARKER

Approved as to style and content by:

R. Mark Leckie, Chair

Robert M. DeConto, Member

Steven T. Petsch, Member

Julie Brigham-Grette, Department Head

Department of Geosciences 


\section{ACKNOWLEDGEMENTS}

I would like to thank my advisor, Mark Leckie, for his thoughtful guidance and support throughout this project. Thanks are also due to my research group for stimulating discussions that helped refine the ideas presented in this thesis. I would also like to extend my gratitude to the members of my committee, Rob DeConto and Steven Petsch, for their helpful comments, suggestions, and constructive reviews during all stages of this project.

I want to thank the National Science Foundation and the University of Massachusetts Amherst Department of Geosciences for funding and supporting this project and providing travel expenses during the writing of this manuscript. I wish to express my appreciation to all individuals who volunteered their participation with this project. I would like to acknowledge Matt Jones and Brad Sageman for their geochemical contributions to this research. Special thanks are given to Chris Lowery and Lindsey Victoria for their efforts in the field, and to Serena Dameron for her help with sample preparation.

A special thank you to my family and Zachary Stromer for their support during the last few years. I would not have been able to complete this thesis without their continuous love and encouragement. 


\begin{abstract}
OCEANIC ANOXIA EVENT 2 ( 94 MA) IN THE U.S. WESTERN INTERIOR SEA: HIGH RESOLUTION FORAMINIFERAL RECORD OF THE DEVELOPMENT OF ANOXIA IN A SHALLOW EPICONTINENTAL SEA

FEBRUARY 2016
\end{abstract}

\author{
AMANDA L. PARKER, B.S., UNIVERSITY OF MARY WASHINGTON \\ M.S., UNIVERSITY OF MASSACHUSETTS AMHERST \\ Directed by: Professor R. Mark Leckie
}

The Upper Cretaceous Tropic Shale of southern Utah is a thick deposit of dark mudrock and shale that captures oceanographic changes that occurred during Oceanic Anoxic Event 2 (OAE 2) in the Western Interior Seaway (WIS), and records environmental perturbations during the transgression of the Greenhorn Sea during the time of the Cenomanian-Turonian boundary interval (CTB; 93.9 Ma). I investigated the response of planktic and benthic foraminifera in a shallow $(<100 \mathrm{~m})$ marine environment stressed by the onset of OAE 2 . This study is based on high-resolution quantitative foraminiferal population counts and isotope paleoecology $\left(\delta^{18} \mathrm{O}\right.$ and $\delta^{13} \mathrm{C}$ ) from a 40-m composite core and outcrop section of the Tropic Shale near Big Water, Utah. The OAE 2 interval is identified by a distinctive $\delta^{13} \mathrm{C}_{\text {org }}$ signature and by correlation of bentonites and carbonate-rich units across the seaway.

Results of assemblage analyses indicate discrete intervals of environmental perturbations across the CTB interval. The basal $6.0 \mathrm{~m}$ of the Tropic Shale are sandy and contain sparse assemblages of agglutinated benthics and very rare specimens of planktic foraminifera. The onset of OAE 2 was rapid, and surface waters were dominated by planktic Guembelitra cenomana with minor species of Heterohelix. Benthic abundances increase at the same time as the planktics and were initially dominated by low oxygen tolerant infaunal Neobulimina albertensis. Epifaunal Gavelinella dakotaensis briefly proliferated as the WIS record of OAE 2 intensified, coinciding with the widespread "Heterohelix shift" and increasing accumulation of organic matter. The peak of OAE 2 at $\sim 17.0 \mathrm{~m}$ is marked by a rapid shift back to Neobulimina 
dominance. We suspect incursion of oxygen-poor Tethyan intermediate waters with approach of peak transgression during the early Turonian, coupled with high productivity in surface waters resulted in the rapid depletion of benthic oxygen. These correlations suggest an intricate relationship among rising sea level, changing water masses, flux of organic matter, and reduced benthic oxygenation. The foraminiferal record reveals strong cyclicity in planktic/benthic ratio resembling parasequences. Based on correlations with more distal sections, this cyclicity is mostly likely driven by changing climatic conditions in the WIS, rather than changes in sea level. 


\section{TABLE OF CONTENTS}

Page

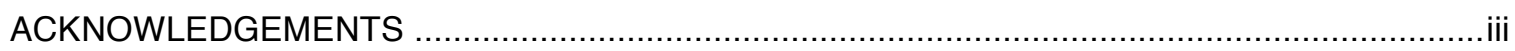

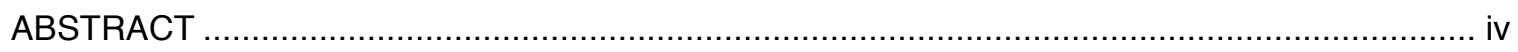

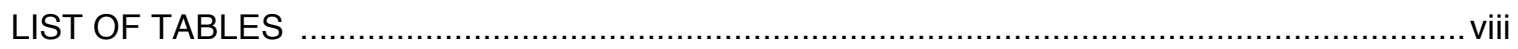

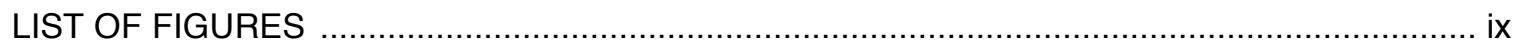

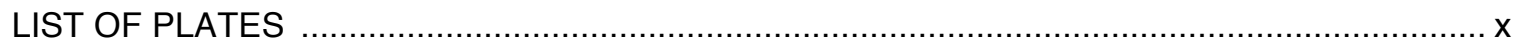

CHAPTER

1. THE LATE CRETACEOUS CLIMATE AND BIOTIC EVENTS ….......................................... 1

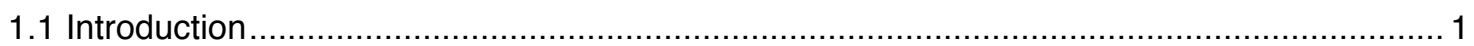

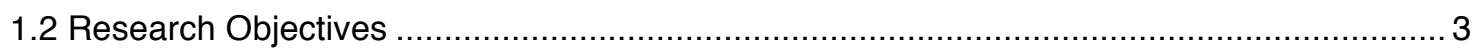

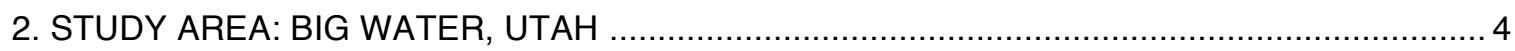

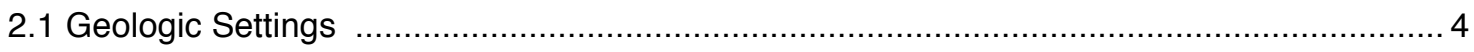

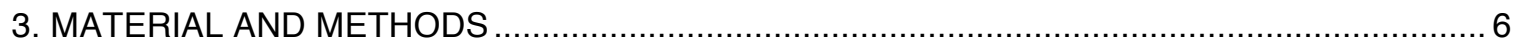

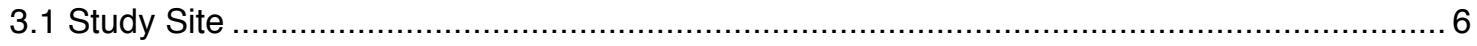

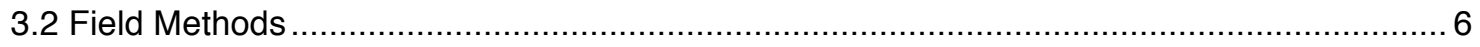

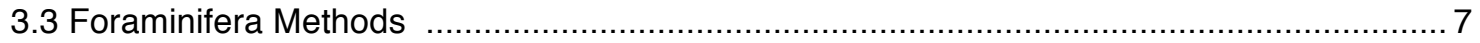

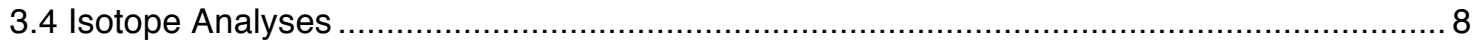

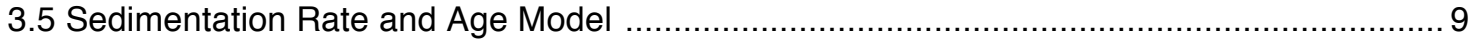

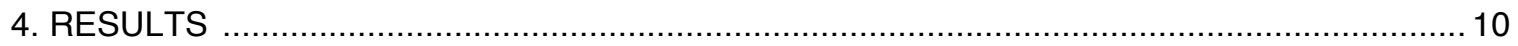

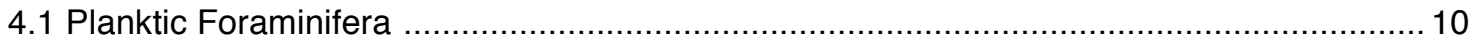

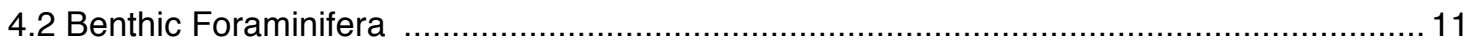

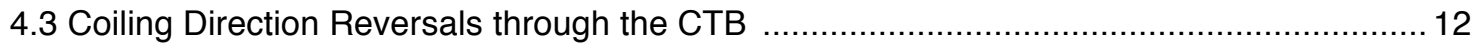

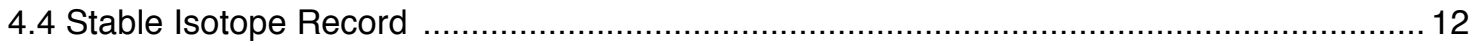

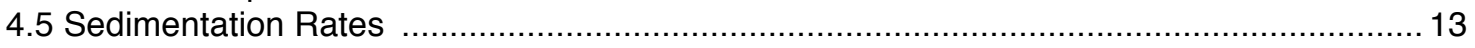

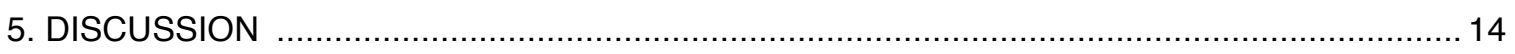

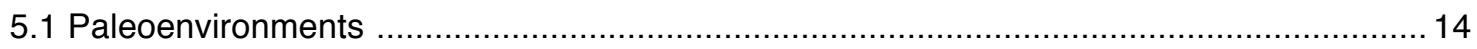

5.1.1 Upper Cenomanian Metoiceras mosbyense Zone .................................................. 15

5.1.2 Upper Cenomanian Sciponoceras gracile Zone ...................................................... 16

5.1.3 Uppermost Cenomanian Neocardioceras juddii Zone ............................................. 17 
5.1.4 Lowermost Turonian Watinoceras devonense Zone and Lower Turonian Mammites nodosoides Zone

5.2 Coiling-Direction Reversals and SST Variations …..................................................... 19

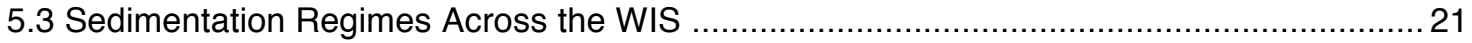

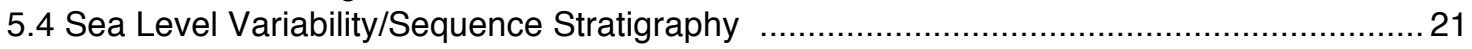

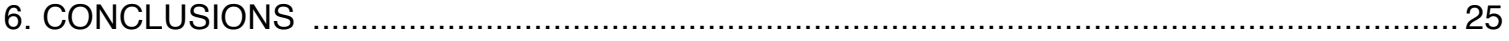

APPENDICES

A. TABLES 


\section{LIST OF TABLES}

Table

Page

1. Planktic Foraminifera Raw Data

2. Benthic Foraminifera Raw Data 34 


\section{LIST OF FIGURES}

Figure

1. Paleogeographic reconstruction of the Colorado Plateau from the Late Cretaceous

2. Chronostratigraphic correlations depicted between southern Utah and the CenomanianTuronian GSSP near Pueblo, Colorado

3. Stratigraphic section near Big Water, Utah

4. Planktic foraminiferal assemblage data from Big Water, Utah

5. Benthic foraminiferal assemblage data from Big Water, Utah

6. Summary figure showing high frequency coiling reversals of \%Sinistral Trochospiral spp. and $\delta^{13} \mathrm{C}_{\text {org }}$ and $\delta^{18} \mathrm{O}_{\text {carb }}$ from the core

7. A comparative stable isotope $\left(\delta^{18} \mathrm{O}\right.$ and $\left.\delta^{13} \mathrm{C}\right)$ study of well-preserved specimens of planktic and benthic foraminifera

8. Sedimentation rates through the Cenomanian-Turonian boundary interval

9a. Proportion of planktic morphotypes to total planktic foraminifera through the CenomanianTuronian boundary interval

9b. Proportion of benthic species to total benthic foraminifera through the Cenomanian-Turonian boundary interval

10. Comparison of \%TOC and benthic foraminifer abundances during OAE 2 .

11. Comparison of bulk carbonate (blue line) and foraminifera (planktic and benthic total abundances) during the OAE 2 event from Big Water, Utah 


\section{LIST OF PLATES}

Plate

Page

1. Planktic foraminifera from the Tropic Shale 54

2. Benthic foraminifera from the Tropic Shale 55 


\section{CHAPTER 1 \\ THE LATE CRETACEOUS CLIMATE AND BIOTIC EVENTS}

\subsection{Introduction}

Thick deposits of calcareous mudstone representing prodeltaic and neritic environments of the Western Interior Seaway dominate the Upper Cretaceous of southern Utah. These sediment facies capture critical oceanographic changes that occurred at the onset of Oceanic Anoxic Event 2 (OAE 2) 94.44 Ma (Laurin et al., 2015), and document environmental perturbations that occurred during the transgression of the third-order Greenhorn Cycle across the basin. The Tropic Shale contains the Cenomanian-Turonian boundary interval (CTB; 93.9 Ma; Meyers et al., 2012a), which provides insight into the complexities of the Late Cretaceous greenhouse, which experienced elevated tectonic activity, submarine volcanism, high global sea level, oxygen deficiency, and the burial of vast amounts of organic matter along continental margins and in epicontinental seas (e.g., Schlanger and Jenkyns, 1976; Kauffman, 1984; Arthur et al., 1987; Schlanger et al., 1987; Bralower et al., 1997; Sageman et al., 1997; Leckie et al., 1998, 2002; Huber et al., 2002; Arthur and Sageman, 2005; Meyers et al., 2005, 2012a, 2012b; Turgeon and Creaser, 2008; Pearce et al., 2009; Jenkyns, 2010; Jarvis et al., 2011).

Despite equable climate conditions, the CTB is marked by extinction and biotic turnover in the marine realm with environmental perturbations associated with ocean anoxia (e.g., Elder, 1989; Leckie et al., 2002). OAE 2 refers to the global widespread deposition of organic carbonrich sediment (black shale) in marine environments (Arthur et al., 1987; Schlanger et al., 1987). The OAE 2 interval is identified by a distinctive $\delta^{13} \mathrm{C}_{\text {org }}$ signature caused by the enhanced burial of isotopically light organic carbon most likely linked to the expansion of deep anoxic zones (Arthur et al., 1987; Schlanger et al., 1987; Sageman et al., 2006). Given its proximal nature along the western margin of the seaway, the Tropic Shale records signals of global OAE 2 complicated by regional influences of water mass stratification and mixing, enhanced productivity due to elevated fluvial input, changes in relative sea level and ocean circulation, benthic ventilation, and 
consequent biotic turnover (e.g., Eicher and Worstell, 1970; Eicher and Diner, 1985; Leckie, 1985; Leckie et al., 1991, 1998; West et al., 1998; Tibert et al., 2003; Elderbak et al., 2014; Lowery et al., 2014).

Current research suggests that OAE 2 was caused by increased productivity driven by the rapid influx of micronutrients linked to hydrothermally sourced large igneous provinces, increased rates of oceanic crust production and/or volcanism that degassed large amounts of $\mathrm{CO}_{2}$ (e.g., Kerr et al., 1997; Kerr, 1998; Bralower et al., 1997; Leckie et al., 2002; Snow et al., 2005; Turgeon and Creaser, 2008; Barclay et al., 2010; Meyers et al., 2012b). An alternate hypothesis is that increased global warming strengthened the hydrologic cycle resulting in increased continental weathering and runoff of nutrients into the oceans that stimulated productivity in the surface waters and created anoxia in bottom waters with the flux of organic matter to the seafloor (e.g., Arthur et al., 1987; Schlanger et al., 1987; Leckie et al., 2002; Sageman et al., 2006; Jenkyns, 2010; Meyers, 2012; Van Helmond et al. 2014).

The CTB in the Western Interior Sea (WIS) is marked by dynamic changes in the population structure of planktic and benthic foraminifera (Leckie, 1985; Leckie et al., 1998; Tibert et al., 2003; Elderbak et al., 2014; Lowery et al., 2014). The development or expansion of oxygendeficient waters in the seaway could impinge on the niche of different foraminifera species and thereby control their "presence" or "absence" in the water column or at the seafloor. This study addresses the response of planktic and benthic foraminiferal assemblages to ecological perturbations that occurred at the onset and duration of OAE 2 with rising sea level along the western margin of the seaway, and it establishes a high-resolution biostratigraphic correlation with the Global Stratotype Section and Point (GSSP) at the Rock Canyon section near Pueblo, Colorado (Leckie et al., 1998; Caron et al., 2006; Elderbak et al., 2014). In addition, data from this study utilizes foraminiferal assemblages for interpreting and understanding relationships between relative sea level change, productivity, and benthic ventilation that occurred during the most prominent oceanic anoxic event of the Late Cretaceous. 


\subsection{Research Objectives}

Our primary objective was to create a new high-resolution foraminifera record at Big Water, Utah and to determine the response of foraminifera in a coastal marine environment stressed by the development of OAE 2 during transgression of the Greenhorn Sea. Questions that we sought to answer were: (1) how do the consequences of OAE 2 affect planktic and benthic foraminiferal assemblages across the CTB along the western prodeltaic shoreline of present-day south-central Utah? (2) What are some potential oceanographic mechanisms (i.e., terrigenous input and surface runoff, productivity, expanding oxygen minimum zone (OMZ), water mass stratification, and alkalinity changes) that may have controlled these shifts and turnovers observed in the foraminifera record? (3) Does the planktic trochospiral morphospecies (Hedbergella) display long-term sea surface temperature (SST) trends indicated by high frequency coiling reversals? (4) Furthermore, can changes in foraminiferal assemblage offer the potential for improved resolution of the timing of sea level fluctuations and water mass changes, or be used to recognize and constrain cycles of relative sea level change across the basin? 


\section{CHAPTER 2}

\section{STUDY AREA: BIG WATER, UTAH}

\subsection{Geologic Settings}

The Cretaceous Western Interior Seaway extended some $6000 \mathrm{~km}$ through the middle of North America and it provided a wide, relatively shallow connection between the polar Boreal and the subtropical Tethys Oceans (Hay et al., 1993). The sea attained its greatest width and depth during the early Turonian Stage of the Greenhorn Cycle. The study site is located at Big Water, positioned along the southern edge of the Kaiparowits Plateau in south-central Utah, represents a coastal, prodeltaic to neritic depositional environment (Figure 1). During the early and middle Cenomanian, fluvial and deltaic sedimentation characterized the Colorado Plateau region, with a primary terrigenous source from the Sevier Highlands (Weimer, 1970). As the Greenhorn transgression pushed the shoreline further west, coarse-grained fluvial and marginal marine sandstone deposits of the Dakota Formation were replaced by fine-grained mudstones of the Tropic Shale. By the late Cenomanian Sciponoceras gracile Biozone, diagentically enhanced carbonate-rich layers, or concretion horizons, equivalent to the limestone beds LS1 to LS4 further east, were deposited across the seaway (Elder, 1991).

Leithold (1994) recognized six fourth-order depositional sequences in the Tropic Shale of southern Utah superposed on the third-order transgressive-regressive Greenhorn Cycle. The area experienced episodic subsidence rates that accompanied high accumulation of fine-grained sediments representative of the nearshore facies of the Western Interior Basin. Superposed on these fourth-order cycles are progradational shoreline deposits that have been attributed to Milankovitch climatic forcing of sediment supply (Elder et al., 1994). Posamentier et al. (1988) and Van Wagoner et al. (1990) termed these progradational shoreline deposits as parasequences and each progradational deposit is bounded by a distinct flooding surface. These parasequences have been correlated with cyclic sedimentation across the basin; the proximal transgressive lags and concretion horizons in Utah correlate with distal limestones in Colorado and Kansas, while progradational sands and silts correlate with the offshore mudrocks and shales 
(Elder et al., 1994). Alternatively, Gale et al. (2008) used high-resolution carbon isotope stratigraphy to correlate rhythmically bedded limestones-shales of central Colorado with cyclical deposits in England. These authors concluded that these uppermost Cenomanian-basal Turonian cycles record eustatic changes in sea level. We have the opportunity to test these hypotheses in southern Utah.

To establish a chronostratigraphic framework for this study, macrofossil assemblages and four basinwide bentonite beds (altered ashfall deposits), designated $A$ to $D$, provide reliable correlation through the late trangressive phase of the Greenhorn Cycle, particularly in the upper Cenomanian Sciponoceras gracile to the lowest Turonian Watinoceras devonense Ammonite Biozones (Figure 2). The well-established stratigraphic framework at the Cenomanian-Turonian boundary GSSP (Kennedy et al., 2005) and global reference for OAE 2 at Rock Canyon, Colorado can easily be correlated to the nearshore sites of southern Utah (Elder, 1991; Elder et al., 1994; Tibert et al., 2003). Four carbonate-rich layers (LS1 to LS4; Elder, 1985, 1989, 1991) form continuous or concretionary limestone beds within the shale of the Sciponoceras gracile biozones. These carbonate units are represented by correlative $0.15-$ to $0.50-\mathrm{m}$ thick limestone beds found throughout most of the central part of the Western Interior Basin (e.g. Hattin, 1971, 1975; Elder, 1991). The deposition of limestone beds and equivalent concretion horizons mark a subsequent improvement in the paleoecology of the upper water column, which reflects increasing carbonate content and increasing influence of a normal marine subtropical water mass into the area. A sharp increase in foraminiferal abundance documents the diachronous transgression and incursion of warmer Tethyan waters across the seaway (Leckie et al., 1998). Previous research on the WIS have used foraminiferal records to reconstruct the OAE 2 across northeastern Arizona, south-central Utah, southern Colorado, eastern Kansas, western lowa, and west Texas (e.g., Eicher and Worstell, 1970; Eicher and Diner, 1985; Leckie, 1985; Leckie et al., 1991, 1998; West et al., 1998; Tibert et al., 2003; Elderbak et al., 2014; Lowery et al., 2014). 


\section{CHAPTER 3 \\ MATERIAL AND METHODS}

\subsection{Study Site}

The Tropic Shale is a $200-\mathrm{m}$ thick succession of generally fine-grained rocks exposed along the Kaiparowits Plateau of southern Utah (Figure 3). The Tropic Shale is dark gray, laminated shale to sandy mudstone. It consists primarily of calcareous mudstone and shale representing prodeltaic environments of the western margin of the Greenhorn Sea, and overlies the highly bioturbated marginal marine facies of the Dakota Formation (Leithold, 1993, 1994; Elder et al., 1994; Leithold and Dean, 1998; Schmeisser McKean and Gillette, 2015). The Tropic Shale forms broad undulating flats with gentle slopes across the field area increasing gradient upsection. Its upper contact is gradational with the overlying shallow marine and deltaic sandstone deposits of the Straight Cliffs Formation (Peterson, 1969). Tropic Shale sediments contain fauna dominated by marine invertebrates, including ammonites (Sciponoceras gracile, Mammites nodosoides), bivalves (Pycnodonte newberryi, Inoceramus spp. Mytiloides spp.), and gastropods (Turritella spp., Perissoptera prolabiata) (Elder, 1987); additionally a variety of vertebrates such as plesiosaurs, mosasaurs, bony fish, sharks, and turtles were discovered in lower portions of the Tropic Shale (Titus et al., 2005; Albright et al., 2007; Schmeisser McKean and Gillette, 2015). The Greenhorn strata changes thickness over short distances, and have been interpreted as resulting from differential uplift and subsidence of basement blocks (Hattin, 1985, 1986; Weimer, 1983; Barlow and Kauffman, 1985). This differential movement produced thickness changes ranging several meters; differences in "local relief" may affect the basin topography between the outcrop and the drill site (e.g. Hay et al., 1993).

\subsection{Field Methods}

Fieldwork was completed in July 2014. One drill core (USGS SH\#1) was collected and two outcrop sections (KPS1 and KPS2) were sampled through the lowermost Tropic Shale along 
several partial sections of the southern Kaiparowits Plateau. A 30-m thick section of Tropic Shale was excavated by hand and by backhoe along the Kaiparowits Plateau east of Big Water (UT), in order to create a composite record for foraminiferal assemblage analysis. The KPS1 and KPS2 outcrops were trenched and excavated to expose a fresh section to be described, measured, and collected for macro- and microfossil samples. KPSI outcrop (0.0-6.0 meters) was sampled between 0.2 to $5.0 \mathrm{~m}$ at a resolution of $20 \mathrm{~cm}$, and sampled between 5.0 to $6.0 \mathrm{~m}$ at a resolution of $5 \mathrm{~cm}$. KPS2 outcrop (6.0-30.0 meters) was sampled between 6.0 to $9.0 \mathrm{~m}$ at a resolution of 5 $\mathrm{cm}$, sampled between 9.0 to $14.8 \mathrm{~m}$ at a resolution of $10 \mathrm{~cm}$, and sampled between 14.8 to 30.0 $\mathrm{m}$ at a resolution of $20 \mathrm{~cm}$. A total of 238 samples were collected from the two outcrop sections for micropaleontological analyzes. A 100-foot-long ( 30.0 m) USGS SH\#1 Core was also collected from the Kaiparowits Plateau near Big Water (UT). A total of 53 samples were collected for continued resolution across the CTB from the USGS SH\#1 Core. Samples were collected from the top $10.0 \mathrm{~m}$ of the USGS SH\#1 Core at $20 \mathrm{~cm}$ for additional micropaleontological analyzes.

\subsection{Foraminifera Methods}

In the laboratory, bulk rock samples were crushed to centimeter size fractions and soaked in a 3\% solution of Quaternary-O for a week. The disaggregated sediment was washed over a $63-\mu \mathrm{m}$ sieve. The residue was dried in an oven at $50-60^{\circ} \mathrm{C}$. The residue was then split using a microsplitter, to a volume of sediment small enough to yield a fairly sparse distribution of particles on a picking tray. Foraminifera were picked from random quarter squares around the tray until at least 300 specimens were collected and mounted onto a microslide. Other biogenic and lithic components were noted. The "first pick" provides the planktic to benthic ratio, expressed as percent planktics. A "second pick" was made on samples containing too few planktic or benthic specimens for population analysis.

Foraminiferal assemblage data collected for each sample included: (1) planktic to benthic ratio (\% planktics), (2) planktic morphotype analysis (\% biserial, triserial, and trochospiral morphotypes), (3) abundance of major benthic species (Neobulimina albertensis and Gavelinella 
dakotensis) or groups of agglutinated taxa, and (4) trochospirally coiled plankic foraminiferal specimens were counted for coiling preference from the spiral side with 4 to 5 globular chambers visible in the last whorl of the specimen. Right coiling (dextral) refers to those specimens that are coiled in a clockwise direction and left coiling (sinistral) to those that shows a counter-clockwise coiling direction.

Paleoecologic and paleoceanographic interpretations are based on foraminiferal proxies, including planktic/benthic $(P / B)$ ratio related to depth and distance from shore (e.g., Jorissen, 1999; Leckie and Olsson, 2003). The foraminiferal assemblages provide information about environment noting the planktic and benthic characteristics based on habitat, water depth position and oxygenation (see summaries in Leckie et al., 1998 and Tibert et al., 2003). The relative abundance of left- or a right-coiling direction of planktic trochospiral morphospecies are related to SSTs; the left-coiled morphotypes being dominant in cold, high northern latitudes, whereas their right-coiled counterparts are found in more temperate warm environments (Ericson, 1959; Bond et al., 1993; Bauch et al., 2003; Darling et al., 2006; Desmares, in review).

\subsection{Isotope Analyses}

Six samples were analyzed for the major species of planktic (Heterohelix globulosa, Guembelitria cenomana, Hedbergella delrioensis) and benthic foraminifera (Gavelinella dakotensis, Neobulimina albertensis) in order to characterize their paleoecology. Between 15 and 80 specimens were measured for each analysis, depending on the shell thickness and size, to obtain a minimum sample mass of $70 \mu \mathrm{g}$. The advantage of analyzing large numbers of specimens is that isotopic differences between species are more clearly expressed rather than variability between individuals (Pearson et al., 1993). Analyses were carried out using a Kiel III automated carbonate preparation device inline with a ThermoElectron Delta-Plus mass spectrometer at the University of Massachusetts, Amherst. The analytical precision $(1 \sigma)$ based on analyses of the NBS-19 standard was $0.03 \%$ for $\delta^{13} \mathrm{C}$ and $0.07 \%$ for $\delta^{18} \mathrm{O}$ relative to the Vienna Pee Dee Belemnite (VPDB) standard. 


\subsection{Sedimentation Rates and Age Model}

High-resolution sampling was taken across the 500-kyr interval of the critical CTB interval represented by the upper Cenomanian Metoicoceras mosbyense, Sciponoceras gracile and Neocardioceras juddii and the lowest Turonian Watinoceras devonense Ammonite Biozones (Tibert et al., 2003). Sedimentation rates were calculated based on radioisotopically dated bentonites (A-D) from the USGS \#1 Portland Core at Rock Canyon, CO (Meyers et al., 2012a). Given the known age of the datums and the average depth at which the datums appear in the core, simple linear sedimentation rates were calculated and used to extrapolate sediment ages:

((Ben. Depth 2) - (Ben. Depth 1)) / ((Ben. Age 2) - (Ben. Age 1))

Assuming constant sedimentation between each well-dated bentonite, an age model was developed:

(1/Sed. Rate) x (Sample - Ben. Depth) + Ben. Age

Sedimentation rates for the CTB boundary interval vary between sites located within the foredeep (Escalante and Big Water, UT) and sites located along the forebuldge (Lohali Point, AZ and Mesa Verde, CO). 


\section{CHAPTER 4}

\section{RESULTS}

\subsection{Planktic Foraminifera}

Major biotic trends in the planktic foraminiferal assemblages analyzed are expressed as relative percentage data (Figure 4; see Appendices A for raw data tables; see Plate 1 for planktic foraminifera descriptions). The lower $6.0 \mathrm{~m}$ of the Tropic Shale is almost completely barren of planktic foraminifera. Washed samples at the very bottom of the formation are almost entirely comprised of sand in the upper Cenomanian Metoicoceras mosbyense zone. Above $6.0 \mathrm{~m}$, the samples contain foraminifera, but frequently did not yield 300 foraminifera specimen per sample. Triserial genus Guembelitria first appears near Bentonite A $(6.25 \mathrm{~m})$ in high abundance and dominates the foraminiferal assemblage through the upper Cenomanian Sciponoceras gracile zone, while biserial Heterohelix and trochospiral Hedbergella and Whitenella are much less common (Figure 4).

At the base of the uppermost Cenomanian Neocardioceras juddii zone the planktic assemblage abruptly shifts from triserial Guembelitria-dominance to biserial Heterohelixdominance at $\sim 12.0 \mathrm{~m}$ (Figure 4). This is referred to as the "Heterohelix shift", which has been observed across the Western Interior Seaway (Leckie, 1985; Leckie et al., 1991, 1998; Elderbak et al., 2014; Lowery et al., 2014; Elderbak and Leckie, in press). Guembelitria and Heterohelix alternately dominate 12.0 to $17.0 \mathrm{~m}$.

At $17.0 \mathrm{~m}$, the planktic assemblage records a transition with increasing percentages of the trochospiral genera Hedbergella and Whiteinella throughout the uppermost Cenomanian Neocardioceras juddii zone, with declining percentage of triserial Guembelitria and generally lower values of biserial Heterohelix. At $22.0 \mathrm{~m}$, the relative abundance of triserial species abruptly decreases, while trochospiral taxa abruptly become more abundant and biserial taxa steadily increase in abundance through the lower Turonian Watinoceras devonense zone. At $32.0 \mathrm{~m}$, the biserial Heterohelix species again dominate $(>50 \%)$ the planktic assemblage, while trochospiral and triserial taxa are generally $<25 \%$ and $<20 \%$ of the planktic assemblage, respectively (Figure 
4). Keeled planktic foraminifera (e.g., species of Rotalipora, Praeglobotruncana, and Dicarinella) are completely absent from all outcrop samples.

\subsection{Benthic Foraminifera}

Major biotic trends in the benthic foraminiferal assemblages analyzed are expressed as relative percentage data (Figure 5; see Appendices A for raw data tables; see Plate 2 for benthic foraminifera descriptions). Benthic foraminifera are nearly absent from the lower $6.0 \mathrm{~m}$ of the Big Water outcrop section with the exception of an interval of agglutinated taxa from 1.0 to $3.0 \mathrm{~m}$ in the Metoicoceras mosbyense zone. Agglutinated species consist of Ammobaculites and Trochamminoides. The interval from 6.0 to $17.0 \mathrm{~m}$ frequently did not yield 300 foraminiferal specimens per sample. Infaunal genus Neobulimina first appears near Bentonite A $(6.15 \mathrm{~m})$ in high relative abundance. Neobulimina dominated the benthic assemblage of the Sciponoceras gracile zone with fewer Gavelinella and sporadic agglutinated occurrences.

In the uppermost Sciponoceras gracile zone, the benthic assemblage abruptly shifts from infaunal Neobulimina-dominance to epifaunal Gavelinella-dominance at $11.5 \mathrm{~m}$. Gavelinella dominates in two main pulses of $\sim 80-90 \%$ straddling Bentonite $B(14.0 \mathrm{~m})$ in the lower Neocardioceras juddii zone, before declining to $5 \%$ at $17.0 \mathrm{~m}$ (Figure 5). This interval has been referred to as the "Gavelinella acme" because of its widespread occurrence across the Western Interior Seaway (Leckie, 1985; Leckie et al., 1991, 1998; Elderbak et al., 2014; Elderbak and Leckie, in press). Neobulimina displays high relative abundances below Bentonite B and between the two Gavelinella pulses. Agglutinated taxa appear in two pulses in this interval with Haplophragmium and Trochammioides dominating the agglutinated taxa.

The benthic assemblage is again dominated by the infaunal genus Neobulimina ( $90 \%)$ following a rapid assemblage change at $17.0 \mathrm{~m}$. This ecological shift from epifaunal Gavelinella acme to infaunal Neobulimina-dominance is somewhat diachronous across the seaway but is a characteristic feature of the uppermost Cenomanian Neocardioceras juddii zone (Leckie et al., 1998; Elderbak and Leckie, in press). In addition to the sharp ecologic change, the sediments 
above 17.0 m yield more abundant foraminifera, with larger specimens of Neobulimina. Both epifaunal Gavelinella and agglutinated taxa remain extremely low in abundance throughout this interval and into the Watinoceras devonense zone.

\subsection{Coiling Direction Reversals through the CTB}

The relative percentage of trochospiral species clearly displays long-term trends punctuated by high frequency coiling reversals (Figure 6). The trochospiral morphotypes are absent until $6.15 \mathrm{~m}$. There is an abrupt increase in sinistral (left-coiled) species beginning at 6.25 $\mathrm{m}$ where the proportion attains more than $70 \%$ relative abundance. The first sinistral event persists through the lower part of the Sciponoceras gracile zone before a sharp decline. Another

abrupt increase in sinistral morphotypes is associated with the position of concretion horizon LS3 $(9.0 \mathrm{~m})$ above Bentonite A. Prior to the concretion horizon LS4 $(10.6 \mathrm{~m})$ there is a drop in the abundance in sinistral morphotypes. A second major pulse in sinistral morphotypes at concretion horizon LS4 $(10.6 \mathrm{~m})$ forms a peak in the upper Sciponceras gracile zone. There is a sharp decrease in sinistral morphotypes at the base of Neocardioceras juddii zone at $\sim 12.0 \mathrm{~m}$ associated with abrupt changes also observed planktic and benthic foraminiferal assemblages, namely the "Heterohelix shift" and "Gavelinella acme", respectively. Sinistral morphotypes show a minor increases in the upper Neocardioceras juddii and basal Watinoceras devonense zones, and again in the Mammities nodosoides zone near the top of the studied section.

\subsection{Stable Isotope Record}

A comparative stable isotope $\left(\delta^{18} \mathrm{O}\right.$ and $\left.\delta^{13} \mathrm{C}\right)$ study of relatively well-preserved specimens of planktic (Heterohelix globulosa, Guembelitria cenomana, Hedbergella delrioensis) and benthic foraminifera (Gavelinella dakotensis, Neobulimina albertensis) enabled us to determine the preferred depth habitat and mode of life for each species (Figure 7). Oxygen isotope values of Heterohelix globulosa range from $-13.48 \%$ o to $-12.12 \%$, and overlap with those of Guembelitria cenomana $(-13.29 \%$ to $-10.55 \%$ ) indicating that their habitat is definitely planktic 
and probably within the surface mixed layer. Carbon isotope values range from $0.30 \%$ o to $2.43 \%$ 。 and are distinctly lower than values for Guembelitria cenomana $-3.55 \%$ o to $1.26 \%$. Biserial planktic foraminifera, such as Heterohelix have previously been interpreted as low-oxygen tolerant meso- to eutrophic thermocline dwellers thriving in variable surface water conditions (Leckie, 1987), and indicative of the presence of an OMZ (Boersma and Premoli Silvia, 1989). Oxygen isotope values of Hedbergella delrioensis range from $-13.0 \% \circ 1$ to $-11.42 \%$ indicating that their habitat is planktic and probably within the upper reaches of the thermocline. Carbon isotope values range from $1.51 \%$ to $2.95 \%$. Oxygen isotope values of Gavelinella dakotensis range from $-12.56 \%$ o to $-9.77 \%$ ond slightly overlap with those of Neobulimina albertensis $-12.52 \%$ o to -

$11.12 \%$. Both taxa consistently have more enriched values compared with the three planktic taxa indicating that their habitat was benthic. Carbon isotope values of Gavelinella dakotensis range from $0.30 \%$ o to $2.17 \%$ and are distinctly lower than values for Neobulimina albertensis $-4.07 \%$ o to $2.04 \%$. Both planktic and benthic foraminifera capture the well-known $\delta^{13} \mathrm{C}$ positive excursion for OAE 2.

\subsection{Sedimentation Rates}

Sedimentation rates were calculated at the four Western Interior Seaway sites (Figure 8). At Escalante (UT), the sedimentation rates varied between 3.0 and $5.0 \mathrm{~cm} / \mathrm{kyr}$, with the largest rate recorded between bentonites C-D. At Big Water (UT), the sedimentation rates varied between 3.7 and $5.4 \mathrm{~cm} / \mathrm{kyr}$, with the largest rate recorded between bentonites B-C. At Lohali Point (AZ), the sedimentation rates varied between 3.0 and $6.6 \mathrm{~cm} / \mathrm{kyr}$, with the largest rate recorded between bentonites C-D. At Mesa Verde (CO), the sedimentation rates varied between 1.2 and $0.4 \mathrm{~cm} / \mathrm{kyr}$, with the largest rate recorded between bentonites A-B. 


\section{CHAPTER 5 \\ DISCUSSION}

\subsection{Paleoenvironments}

The ratio of planktic to benthic foraminifera (P/B ratio, or \%planktic to total foraminifera) is commonly used as a qualitative proxy for sea level and proximity to shore (e.g., Leckie and Olson, 2003). Proportions of major morphogroups of planktic foraminifera are also useful as proxies for water column stratification (Leckie, 1987; Huber et al., 1995; Hart, 1999), including triserial and biserial (genera Guembelitria and Heterohelix, opportunistic surface-dwelling genera that dominated stressful environments), trochospiral (large, inflated upper thermocline to surface dwelling genera that include species of genera Hedbergella and Whiteinella), and keeled taxa (species of Rotaliporia, Praeglobotruncana, and Dicarinella generally lived at thermocline depths and/or normal marine conditions; e.g., Corfield et al., 1990; Norris and Wilson, 1998; Petrizzo et al., 2008).

The relative portion of infaunal to epifaunal benthic foraminifera are useful as proxies for bottom water oxygenation, as well as the availability and quality of organic matter at the sediment water interface (e.g., Bernhard, 1986; Sen Gupta and Machain-Castillo, 1993; Kaiho, 1994; Jorissen et al., 1995; Jorissen, 1999; Ashckenazi-Polivoda et al., 2010). In this study, the dominant calcareous benthic taxa include infaunal Neobulimina albertensis, a presumed lowoxygen tolerant serial taxon, and epifaunal Gavelinella dakotensis, a flat, trochospirally-coiled taxon that may have responded quickly to the input of terrestrial or marine organic matter (Leckie et al., 1991, 1998; Gooday, 1993; Thomas and Gooday, 1996; West et al., 1998).

Few species of benthic foraminifera can survive in dysoxic to anoxic environments; such environments consist of low abundances and low diversity assemblages (e.g., Koutsoukos et al., 1990; Kaiho, 1994; Erbacher et al., 1999; Holbourn and Kuhnt, 1998; Kaiho, 1999; Leckie and Olsson, 2003; Gebhardt, 2004; Kuhnt et al., 2005; Friedrich et al., 2009; Friedrich, 2010). 
Planktic foraminifera with trochospirally arranged tests exhibit a left (sinistral) or a right (dextral) coiling direction. These planktic morphotypes have been classically used to constrain glacial and interglacial climates based on this temperature-dependent coiling-direction proxy (e.g., Ericson, 1959; Bond et al., 1993; Norris and Nishi, 2001). In a recent study by Desmares et al. (in review), the relative coiling preference of Muricohedbergella delrioensis was related to sea surface temperature (SST) variations across the CTB.

\subsubsection{Upper Cenomanian Metoicoceras mosbyense Zone}

The Metoicoceras mosbyense zone $(0.0-6.0 \mathrm{~m})$ is completely devoid of planktic foraminifera until $6.20 \mathrm{~m}$ indicating stressful or uninhabitable conditions in the upper water column, perhaps due to low salinity from fluvial/deltaic influx from the Sevier Highlands. Low oxygen levels at/or below the sediment water interface have been suggested as an explanation for the barren benthic assemblages; however, the lower $6.0 \mathrm{~m}$ of the Tropic Shale consists of muddy sandstone to sandy or silty mudstones. The siliclastics are likely derived from the Sevier Highlands and reworked during the rapid transgression. High TOC values up to 3 wt. $\%$ in the lower $3.0 \mathrm{~m}$ of the USGS SH\#1 Core also indicate hypoxic bottom water conditions resulting in better preservation of organic matter. Equivalent sections in Escalante (UT), Lohali Point (AZ), Mesa Verde (CO), and Rock Canyon (CO) are characterized by very low values (1 wt.\%) of TOC, but still lack benthic foraminifera (Eischer and Worstell, 1970; Leckie et al., 1998; West et al., 1998; Caron et al., 2006; Elderbak et al., 2014).

Surface runoff from the Sevier Highlands provided the basin with higher terrestrial organic matter flux and enhanced water column stratification by means of the creation of a low-density estuarine-like freshwater cap (Elderbak et al., 2014). In shallow marine environments, the development of hypoxic conditions in bottom waters resulted from the discharge of excess nutrients and freshwater into the basin leading to enhanced primary productivity and eutrophication in the upper water column. Kauffman (1975) suggested low salinity surface waters might have inhibited the migration of species into the seaway. Arthur et al. (1985) interpret $26^{\circ} \mathrm{C}$ 
surface water temperatures that suggests $\delta^{18} \mathrm{O}$ indicates a decrease in salinity of surface water of $22 \%$. Average ocean salinity today is $35 \%$; with a $22 \%$ reduction the salinity becomes $28 \%$, which suggests the presence of a brackish water (estuarine) lid in the seaway. The occurrence of agglutinated foraminifera Ammobaculites and Trochamminoides (1.0 to $3.0 \mathrm{~m}$ ) supports the idea of estuarine conditions in southern Utah during the Metoicoceras mosbyense zone (Tibert et al., 2003, 2013).

\subsubsection{Upper Cenomanian Sciponoceras gracile Zone}

During deposition of the Sciponoceras gracile zone (6.0-12.0 m), rising sea level and continued transgression (Arthur and Sageman, 2005) brought warm, oxygenated, normal marine waters into the basin creating favorable conditions for the development of a calcareous foraminiferal assemblage (Figure 5; Eicher and Worstell, 1979; Kauffman, 1984; Eicher and Diner, 1985; Leckie et al., 1998; Elderbak and Leckie, in press). A low diversity planktic foraminiferal assemblage dominates with Guembelitria with minor proportions of Heterohelix; both genera are generalist surface-dwelling taxa characteristic of epicontinental seas across the WIS (Figures 4, 9a; Eicher, 1969; Leckie, 1985, 1987; Leckie et al., 1998; Tibert and Leckie, 2013; Elderbak et al., 2014). The rapid increase in the proportion of benthic foraminifera (e.g. "Benthonic Zone;" Eicher and Worstell, 1970) marks the abrupt ventilation and improvement in bottom water conditions at the site, as well as reduced sediment flux. The onset of this transgression coincides with the initial positive $\delta^{13} \mathrm{C}$ excursion marking the onset of OAE 2.

This benthic oxygenation event is recorded at Lohali Point (AZ), Mesa Verde (CO), Rock Canyon (CO), and Cuba (KA) (Leckie et al., 1998; West et al., 1998; Elderbak et al., 2014) and represents a synchronous event across the basin (Figure 9b). At Big Water, the "Benthonic Zone" is represented by two species of benthic foraminifera that are calcareous with southern affinities: Gavelinella dakotensis and Neobulimina albertensis. The two distinct benthic foraminifera are characterized as epifaunal (Gavelinella) and infaunal (Neobulimina) based on morphology and presumed microhabitat preference. 


\subsubsection{Uppermost Cenomanian Neocardioceras juddii Zone}

The Neocardioceras juddii zone is represented by a sharp increase in epifaunal Gavelinella dakotensis and decline in infaunal Neobulimina albertensis (Figure 5). Gavelinella is inferred as an opportunistic species capable of taking advantage the new niches opened by the transgressing seaway and sporadic/seasonal input of terrestrial and/or marine detrital organic matter (Leckie et al., 1998). The "Gavelinella acme" is recorded across the basin and has been interpreted as a productivity event (Figure 9b; Leckie et al., 1998; West et al., 1998; Elderbak et al., 2014). Leckie et al. (1998) suggested that upwelling of cool nutrient rich waters along the WIS forebulge stimulated productivity resulting in an increased delivery of organic matter to the seafloor. Supporting this productivity hypothesis are the increased pulses of agglutinated benthics Haplophragmium and Trochammioides whose occurrence is often associated with Gavelinella in distal shelf environments (Tibert and Leckie, 2013). TOC values increased significantly (to 3 wt.\%) at Big Water corresponding to increasing Gavelinella abundance suggesting favorable conditions for organic matter preservation (Figure 10).

With continued transgression, warm subtropical Tethyan water masses invaded the seaway and widely distribute distinct foraminifera assemblages, which can be diachronously traced across the seaway first at Mesa Verde (CO), then Lohali Point (AZ), and ending with Big Water and Escalante (UT) (see Figure 9b). Despite the diachronous species changes in the benthic assemblages, planktic assemblages also abruptly changed from triserial dominance to biserial dominance (Figures 4, 9a). This is an isochronous event recognized across the seaway as the "Heterohelix shift". Initially, the "Heterohelix shift" was hypothesized to be the result of increased runoff into the basin or incursion of an oxygen minimum zone (Leckie, 1985; Leckie et al., 1991, 1998). Elderbak and Leckie (in press) now suggest that the "Heterohelix shift" records a major change in the surface water mass across the southern WIS that reflects greater runoff and higher productivity, and less influence from Tethys. In addition, there is a general increase in planktic trochospiral morphotypes (Hedbergella and Whiteinella) representative of the deeper, 
more open marine conditions with greater stratification between the mixed layer and upper thermocline. Lack of deep-water dwelling keeled species like Rotalipora suggests shallow depth and/or poor normal marine conditions. Cyclical changes in planktic foraminiferal assemblages that alternate between Heterohelix dominance and Guembelitria dominance suggests dynamic changes in surface water mass conditions along the western margin of the WIS, including productivity, during the latest Cenomanian.

Fluctuating TOC values in the Neocardioceras juddii Zone ( $<1$ to $3 \mathrm{wt} . \%)$ may also indicate less sporadic/seasonal influx of organic matter and/or poor preservation at the seafloor; likewise, an increased influx of biogenic carbonate to the seafloor associated with the incursion of warm southern water mass may have created a significant change in the nature of the substrate allowing for diverse benthic foraminiferal assemblages (Elderbak et al., 2014). The Neocardioceras juddii Zone coincides with the plateau of elevated $\delta^{13}$ Corg values marking the core of OAE 2 (Figure 6; Sageman et al., 2006). The diachronous "Gavelinella acme" may represent the initial WIS record of higher productivity and greater preservation of TOC associated with OAE 2 across the seaway. An abrupt change to dominance by Neobulimina albertensis in the middle of this zone (17 $\mathrm{m}$ in the Big Water outcrop section) likely signals an isochronous intensification of dysoxic to anoxic conditions across the seaway recording the peak of OAE 2 in the WIS (Leckie et al., 1998; Elderbak et al., 2014; Elderbak and Leckie, in press).

\subsubsection{Lowermost Turonian Watinoceras devonense Zone and Lower Turonian Mammites nodosoides Zone}

The dramatic ecologic shift that occurred at $\sim 17.0 \mathrm{~m}$ in the upper Neocardioceras juddii continued into the lower Turonian Watinoceras devonense and Mammites nodosoides zones and created a stressed habitat for both planktic and benthic communities. The abrupt increase in the infaunal benthic species Neobulimina suggests the incursion of an oxygen minimum zone of Tethyan affinity approaching peak transgression of the Greenhorn Sea (Leckie et al., 1998; Elderbak and Leckie, in press), or the development of oxygen-poor conditions such as a coastal 
dead zone (e.g., Elderbak et al., 2014). Approaching peak transgression, bottom water conditions were significantly stressed as indicated by the continued dominance of Neobulimina above the OAE 2 interval. Surface water conditions may have also become increasingly stressed as suggested by the decrease in triserial Guembelitria abundances through the lowermost Turonian and decline in trochospiral taxa, especially in the Mammites nodosoides Zone where biserial Heterohelix (Figures 4 and 9a).

This biofacies may have been associated with the expansion of intermediate dysoxic southern waters into the area with continued sea level rise. TOC values gradually decline $(<1$ wt.\%) as the plateau of positive $\delta^{13} \mathrm{C}_{\text {org }}$ values began to decline, marking the end of OAE 2. The low-oxygen tolerant, infaunal Neobulimina continued to dominate the benthic foraminiferal assemblage with sporadic occurrence of epifaunal Gavelinella suggesting dysoxic organic-rich conditions at the seafloor (Figure 5). High productivity in surface waters coupled with increased sedimentation rates, resulted in rapid depletion of benthic oxygen, to which benthic foraminifera were unable to proliferate under anoxic conditions even though food was abundant (West et al., 1998). Under dysoxic conditions, a critical level of oxygen was more important than food; lowoxygen tolerant infaunal Neobulimina could proliferate and exclude epifaunal Gavelinella that require higher oxygen levels. A comparable trend has been recorded in the central and eastern parts of the seaway and denotes impingement of an oxygen minimum zone from the south (Leckie et al., 1998; Elderbak et al., 2014).

\subsection{Coiling-Direction Reversals and SST Variations}

Coiling-direction reversals among sinistral morphotypes are likely to be due to SST variations and are similar to the interpretations by Desmares et al. (in review). In the Western Interior Seaway, the first cooling event (Figure 6; S1b) is recorded equivalent LS2 (above Limestone Bed 63 in the Hartland Shale GSSP; Caron et al., 2006) the $\delta^{18} \mathrm{O}_{\text {carb }}$ values are lowered perhaps due to subsaline conditions (as a freshwater estuarine cap or increased surface runoff from the Highlands). Following this initial increase in sinistal forms at the beginning of the 
Sciponoceras gracile zone, a sharp and short drop in the percentage of sinistral forms occurs, which is coincident with the first peak "A" of the $\delta^{13} \mathrm{C}_{\text {org }}$ curve (Figure 6; Pratt and Threlkeld, 1984; Pratt, 1985). This decrease in sinistral form could be linked to a major $\mathrm{CO}_{2}$ pulse attributed to intense volcanic activity accompanying the initial emplacement of the Caribbean large igneous plateau (Snow et al., 2005; Turgeon and Creaser, 2008; Barclay et al., 2010). Notably numerous bentonites occur within this episode of intense volcanic activity across the seaway. After this brief episode of SST warming, the percentage of sinistral forms increases.

The high abundance of sinistral morphotypes coincident with high $\delta^{18} \mathrm{O}_{\text {carb }}$ values could be a response to this decline in global SSTs. This cooling event is well documented across northwest Europe and in the North Atlantic, where the positive $\delta^{18} \mathrm{O}_{\text {carb }}$ excursion coincides with the Plenus Cool Event, a period or extensive bottom-water reoxidation and temporary invasion of Boreal fauna throughout the North Atlantic (Jefferies, 1962, 1963; Gale and Christensen, 1996; Jarvis et al., 2002, 2011), South America (Demerara Rise; Friedrich et al., 2006), North Africa (Morocco; Keller and Pardo, 2004), and in North America (Leckie et al., 1998). This second cooling event (S2) is synchronous with the Plenus Cool Event. Additionally, Jarvis et al. (2011) attribute ocean cooling to the decrease in $\mathrm{pCO}_{2}$ due to carbon sequestration by marine organic productivity and nutrient recycling in continental margins, ultimately leading to the return of anoxia (Sinninghe Damste and Koster, 1998; Kuypers et al., 2002; Jenkyns et al., 2007), and black shale accumulation (peak OAE 2) during the latest Cenomanian in these settings.

The rapid decrease of sinistral morphotypes throughout the Neocardioceras juddii zone suggests that with continued volcanogenic $\mathrm{CO}_{2}$ increased SSTs once again during the main interval of OAE 2. This renewed atmospheric $\mathrm{CO}_{2}$ could have overridden the initial drawdown effects stated by Jarvis et al. (2011). The core of the OAE 2 interval is marked by the "Heterohelix shift" in the WIS. Following the brief recovery "B" of the main isotopic $\delta^{13} \mathrm{C}_{\text {org }}$ excursion (Figure 6; Pratt and Threlkeld, 1984; Pratt, 1985) the low abundance of sinistral morphotypes (identified as dextral warming events $a, b, c, d$ ) indicates warm SSTs during the early Turonian across the seaway. This progressive continued decrease of sinistral forms throughout the Neocardioceras 
juddii zone coincides with the sustained plateau "C" of the $\delta^{13} \mathrm{C}_{\text {org }}$ curve (Figure 6; Pratt and Threlkeld, 1984; Pratt, 1985), which spans the warm interval of OAE 2.

\subsection{Sedimentation Regimes Across the WIS}

The Sevier Orogeny was a narrow, continuous fold and thrust belt along the western margin of the seaway (Parrish, 1993). Tectonic loading created a large, asymmetric foreland basin, where the position of the foredeep and forebuldge contributed greatly to the extent of sediment accumulation at each site (Figure 8). Apart from depth of the basin, the shelf slope and shoreline position greatly contributed to the extent of sedimentation at each site. Escalante and Big Water (UT) were positioned in the foredeep, and experienced higher sedimentation rates than Lohali Point (AZ) and Mesa Verde (CO) that were positioned along the topographic high of the forebuldge. With the transgressing Greenhorn Sea, the sedimentation rates the sites decreased, while the shoreline moved further westward. An exception to this is perhaps the proximity of Escalante to the Sevier Highlands and the movement of Lohali Point from the forebuldge into the foredeep. The increase in sedimentation after Bentonite $C$ suggests that subsidence in the foredeep created uplift at the forbulge and the dramatic increase in sedimentation at Lohali Point (Figure 8).

\subsection{Relative Sea Level Variability/Sequence Stratigraphy}

Higher frequency relative sea level trends across the Cretaceous Western Interior Seaway are well known and have been studied extensively in Utah (Leithold, 1994; Elder et al., 1994; Laurin and Sageman, 2007). Given its proximity along the western margin, the area experienced episodic subsidence that accompanied high rates of sediment accumulation in marginal-marine environments providing a highly detailed record of shoreline movements (Laurin and Sageman, 2007). Leithold (1994) identified numerous fifth-order parasequences across the region. Upward within each parasequence the sediment grain size increases and weight percent 
of carbonate decreases; across the parasequence boundary, or marine flooding surface, grain size decreases and carbonate content increases, indicating an episode of relative deepening.

Following this initial recognition, Elder et al. (1994) proposed that these parasequence boundaries, or rapid transgressive events, could be traced eastward across the basin into discrete limestone concretion horizons and limestone beds in the central parts of the WIS. Peaks in carbonate represent periods of maximum flooding along the western margin coinciding with increased \% P. An integrated model of orbitally induced changes in sea level, carbonate productivity, and terrigenous sediment input provide a plausible explanation of the of the apparent basin wide cyclic sedimentation. Planktic and benthic foraminiferal population trends (see Figure 11), as well as sedimentary features (macrofossil debris, calcispheres, concretion horizons, etc.) record relative sea level changes across the Tropic Shale and serve to augment Elder et al. (1994) conclusions that rhythmic deposition is primarily orbital forcing of insolation and climate.

The development of shoreface parasequences has been attributed to Milankovitch climate forcing of sediment supply and eustasy seem a plausible cause for the apparent relative changes in sea level associated with cyclic sedimentation at the basin margin and carbonate cycles in the basin center (Elder et al., 1994). Obliquity amplified during the duration of OAE 2 record $\sim 40 \mathrm{kyr}$ cycles of the fifth-order parasequence development. During the dry phase of the orbital cycle warm, clear water periods may have favored planktic carbonate productivity and enhanced carbonate deposition. Marine flooding events resulted in increased \% $\mathrm{P}$, corresponding to the deposition of limestone beds across the seaway. During the wet phase of the orbital cycle high rainfall and surface runoff generated strandline progradation, and records the dilution of foraminifera and accumulation of clay-rich sediments across the seaway.

With rising sea level, expanded shelf areas provide increased opportunities for neritic and benthic foraminifera to gain access to the pelagic realm. There is no microfossil evidence for parasequences across the Metoicoceras mosbyense zone. Throughout the $4.0 \mathrm{~m}$ interval the sediment consists of fine-grained sand, an indication of marginal environments with restricted marine affinity into the locale. Agglutinated benthic foraminifera appear briefly during a slightly 
muddy interval between 1.0 to $3.0 \mathrm{~m}$. The appearance of Ammobaculites and Trochamminoides indicate the waters were estuarine (Tibert et al., 2013). As the sea level continued to rise during the late Cenomanian Sciponoceras gracile zone, these conditions abated, and gave way to the influx of subtropical Tethyan waters and more marine fauna.

There are four episodes of rapid transgression; following the abrupt and dramatic \%P increases (identified as Cycle 1 in Figure 11). Following these transgressive pulses, the P/B ratio shows a stepwise decrease in \% $\mathrm{P}$, which record a period of overall strand-plain progradation of the shoreline. The first significant transgressive event is represented by flooding surface concurrent with LS2 followed by a parasequence as it correlates with the lithological and faunal changes at the base of the Sciponoceras gracile zone. Similarly the position of LS3 and LS4 are concurrent with episodes of rapid transgression, in which two more parasequences record an overall period of strand-plain progradation interrupted by two intense pulses of rapid transgression similar to interpretations by Elder et al. (1994). These relative abundance peaks of planktic foraminifera occur with high bulk carbonate percentages, and serve as evidence of maximum flooding events (West et al., 1998; Tibert et al., 2003).

With the rising sea, sedimentation continued to increase giving way to planktic and benthic foraminiferal population trends. The dramatic increase in the percentage of planktic foraminifera during this interval is presumably caused by the improving bottom water conditions created by rising sea level (Leckie et al., 1998; Lowery et al., 2014). This time is conformable and is generally agreed to represent a isochronous flooding surface deposited as sea level rose rapidly and pelagic carbonate sedimentation began (e.g. Elder et al., 1994; Tibert et al., 2003; Meyers and Sageman, 2004; Arthur and Sageman, 2005; Laurin and Sageman, 2007). Following episodic rapid transgression events, the shoreline retreated and the benthic foraminifera who are more adapt to live and thrive in the muddy, less saline surface waters (greater runoff/estuarine cap) show a relative increase in abundance; whereas planktic foraminifera retreat to more distal deep marine waters. 
Several transgressive flooding events are condensed within the Neocardioceras juddii zone. This interval marks fifth-order parasequences superposed on fourth-order cyclic trends (identified as Cycle 2 in Figure 11) with a decrease in benthic foraminifera toward maximum flooding surfaces. There are roughly eight episodes of rapid transgression; following the abrupt and dramatic \% $\mathrm{P}$ increases. The overall decrease in $\mathrm{P} / \mathrm{B}$ ratio implies that the marine conditions were less favorable to the planktic community during the main OAE 2 interval. Increased organic matter productivity is highly sensitive to sea level fluctuations, especially in surface waters that vary seasonally in productivity and in changing water masses (Leckie et al., 1998). The flux of organic matter to the seafloor will greatly stimulate benthic productivity, and although the flux of planktic foraminifera will be high, there is a greater increase in the relative abundance of benthic foraminifera.

By the lower Turonian Watinoceras devonense zone there is an increase in the relative percentage of planktics, suggesting a return to more normal marine conditions at peak transgression of the Greenhorn Sea. There are three episodes of rapid transgression; following the abrupt and dramatic \%P increases (Figure 11). The late Cenomanian-early Turonian sea level rise brought increased communication with the subtropical Tethys Ocean and decreased stratification, eventually culminating in a dramatic increase in normal marine taxa and benthic foraminifera and temporarily ventilation of the water column (Eicher and Worstell, 1970; Leckie, 1985; Elderbak et al., 2014; Lowery et al., 2014). The spatial and temporal arrangement of P/B ratio of foraminifera compared to the Total Foraminifera, Total Calcispheres, and Carbonate Content indicates that during an overall transgressive period in the Greenhorn Cycle there were several sets of seaward stepping parasequences. These sets were separated by transgressive flooding events of greater magnitude than the transgressive events bounding the parasequences within the sets. These flooding surfaces can be physically trace basinward into discrete fossiliferous concretion horizons and limestone-shale couplets further east (Elder, 1991; Laurin and Sageman, 2007). 


\section{CHAPTER 6 \\ CONCLUSIONS}

Upper Cenomanian-middle Turonian ( 94.4-93.6 Ma) Tropic Shale of south-central Utah represents a prodeltaic muddy shelf situated in the region of an active foredeep adjacent to the Sevier fold and thrust belt. The Tropic Shale records the diachronous transgression of the thirdorder Greenhorn Sea during the late Cenomanian, and a shallow water record of Oceanic Anoxic Event 2 (OAE 2). The Greenhorn Sea was influenced by cooler Boreal water masses from the north and warmer, more normal marine Tethyan water masses from the south. The Tropic Shale is associated with a low diversity assemblage that shows major changes in the variable abundances of planktic and benthic foraminifera. Changes in coiling direction of trochospirally coiled planktic foraminifera (mainly Hedbergella) may signal changes in these two water masses across the area. The temporal and spatial distribution of foraminifera result from an intricate relationship among changing water masses, flux of terrestrial and marine organic matter, reduced benthic oxygenation, sea surface temperature variations, and consequent biotic turnover.

Agglutinated benthic foraminifera of the Metiococeras mosbyense zone record inner shelf conditions early in the Greenhorn transgression. The dominance of triserial planktic Guembelitria cenomana in the upper Cenomanian Sciponoceras gracile zone suggests reduced salinities and elevated productivity in the shelf waters of the western Greenhorn Sea. The appearance of calcareous benthics at the base of the $S$. gracile zone coincides with rapid and widespread improvement of seaway circulation and ventilation with rising sea level. This interval is equivalent to the diverse "Benthonic Zone" elsewhere in the seaway, and is correlative with the Plenus Cold Event of northwest Europe (Elderbak and Leckie, in press). Elevated percentages of sinistrally coiled planktic foraminifera suggest the stronger influence of Boreal surface waters at this time.

An abrupt increase in the biserial planktic genus Heterohelix at the Sciponoceras gracile/Neocardioceras juddii zone boundary marks a rapid change in surface ocean conditions; the "Heterohelix shift" is an isochronous event that is recognized across the Western Interior Sea 
and is likely related to the environmental effects of OAE 2, including elevated productivity and development of water column anoxia. Dextrally coiled planktic foraminifera dominate the assemblages suggesting the greater influence of Tethyan surface waters at the time of the "Heterohelix shift". An acme of the opportunistic epifaunal benthic Gavelinella dakotaensis predates the "Heterohelix shift" at Big Water, whereas in the center of the seaway, the "Gavelinella acme" postdates the "Heterohelix shift" suggesting that a zone of higher productivity was diachronous from the basin center to the west coast as the WIS record of OAE 2 intensified.

An abrupt increase in the opportunistic infaunal Neobulimina albertensis in the uppermost Cenomanian at Big Water (17.0 $\mathrm{m}$ in the section) signals the development or incursion of an oxygen minimum zone $(\mathrm{OMZ})$ in the seaway associated with the peak of OAE 2. A similar shift to Neobulimina dominance is observed across the seaway, although the timing may be somewhat diachronous within the N. juddii Zone (Leckie et al., 1998; Elderbak et al., 2014). The continued dominance of Neobulimina beyond the duration of OAE 2 suggests that anoxia or dysoxia persisted in the western seaway through the time of peak transgression in the early Turonian. High productivity in surface waters, coupled with higher sedimentation rates, resulted in rapid depletion of benthic oxygen, to which epifaunal Gavelinella species were unable to proliferate under anoxic conditions despite the abundance of food.

A highly detailed record of shoreline movements was recorded in the prodeltaic muddy shelf deposits of the Tropic Shale. Within these sediments, we recognize numerous fifth-order parasequences superposed on fourth-order cyclcity as identified by Leithold (1994) and Elder et al. (1994). The positions of parasequence boundaries within the fine-grained successions of the Tropic Shale are best recorded in the planktic/benthic ratio, or \%planktic data. We interpret the presence of fifteen fifth-order parasequences as evidence of climate cyclicity affecting continental runoff (e.g., Laurin and Sageman, 2007), productivity, or circulation along the western margin of the seaway. 
APPENDIX A

TABLES 
Table 1: Planktic Foraminifera Raw Data

\begin{tabular}{|c|c|c|c|c|c|c|c|c|c|}
\hline \multirow{2}{*}{$\begin{array}{l}\text { Sample } \\
\text { Depth } \\
\text { (Meters) }\end{array}$} & \multicolumn{4}{|c|}{ Planktic Morphotypes } & \multirow{2}{*}{$\begin{array}{l}\text { Sample } \\
\text { Depth } \\
\text { (Meters) }\end{array}$} & \multicolumn{4}{|c|}{ Planktic Morphotypes } \\
\hline & Triserial & Biserial & Trochospiral & $\begin{array}{c}\text { Planktic } \\
\text { Total } \\
\end{array}$ & & Triserial & Biserial & Trochospiral & $\begin{array}{c}\text { Planktic } \\
\text { Total } \\
\end{array}$ \\
\hline 0 & 0 & 0 & 0 & 0 & 13.1 & 43 & 95 & 28 & 166 \\
\hline 0.2 & 0 & 0 & 0 & 0 & 13.2 & 61 & 42 & 10 & 113 \\
\hline 0.4 & 0 & 0 & 0 & 0 & 13.3 & 112 & 82 & 8 & 202 \\
\hline 0.6 & 0 & 0 & 0 & 0 & 13.4 & 32 & 101 & 2 & 135 \\
\hline 0.8 & 0 & 0 & 0 & 0 & 13.5 & 4 & 48 & 4 & 56 \\
\hline 1 & 0 & 0 & 0 & 0 & 13.6 & 0 & 21 & 0 & 21 \\
\hline 1.2 & 0 & 0 & 0 & 0 & 13.7 & 0 & 0 & 0 & 0 \\
\hline 1.4 & 0 & 0 & 0 & 0 & 13.8 & 4 & 1 & 1 & 6 \\
\hline 1.6 & 0 & 0 & 0 & 0 & 13.9 & 3 & 0 & 0 & 3 \\
\hline 1.8 & 0 & 0 & 0 & 0 & 14 & 0 & 9 & 2 & 11 \\
\hline 2 & 0 & 0 & 0 & 0 & 14.1 & 0 & 37 & 9 & 46 \\
\hline 2.2 & 0 & 0 & 0 & 0 & 14.2 & 0 & 0 & 0 & 0 \\
\hline 2.4 & 0 & 0 & 0 & 0 & 14.3 & 0 & 0 & 0 & 0 \\
\hline 2.6 & 0 & 0 & 0 & 0 & 14.4 & 89 & 6 & 0 & 95 \\
\hline 2.8 & 0 & 0 & 0 & 0 & 14.5 & 0 & 0 & 0 & 0 \\
\hline 3 & 0 & 0 & 0 & 0 & 14.6 & 0 & 0 & 0 & 0 \\
\hline 3.2 & 0 & 0 & 0 & 0 & 14.7 & 0 & 0 & 0 & 0 \\
\hline 3.4 & 0 & 0 & 0 & 0 & 14.8 & 375 & 119 & 25 & 519 \\
\hline 3.6 & 0 & 0 & 0 & 0 & 14.9 & 0 & 0 & 0 & 0 \\
\hline 3.8 & 0 & 0 & 0 & 0 & 15 & 263 & 80 & 25 & 368 \\
\hline 4 & 0 & 0 & 0 & 0 & 15.2 & 17 & 28 & 12 & 57 \\
\hline 4.2 & 0 & 0 & 0 & 0 & 15.4 & 11 & 10 & 2 & 23 \\
\hline
\end{tabular}




\begin{tabular}{|c|c|c|c|c|c|c|c|c|c|}
\hline 4.4 & 0 & 0 & 0 & 0 & 15.6 & 57 & 5 & 10 & 72 \\
\hline 4.6 & 0 & 0 & 0 & 0 & 15.8 & 22 & 2 & 4 & 28 \\
\hline 4.8 & 0 & 0 & 0 & 0 & 16 & 9 & 8 & 5 & 22 \\
\hline 5 & 0 & 0 & 0 & 0 & 16.2 & 0 & 19 & 5 & 24 \\
\hline 5.05 & 0 & 0 & 0 & 0 & 16.4 & 5 & 27 & 5 & 37 \\
\hline 5.1 & 0 & 0 & 0 & 0 & 16.6 & 0 & 10 & 1 & 11 \\
\hline 5.15 & 0 & 0 & 0 & 0 & 16.8 & 14 & 36 & 25 & 75 \\
\hline 5.2 & 0 & 0 & 0 & 0 & 17 & 14 & 0 & 4 & 18 \\
\hline 5.25 & 0 & 0 & 0 & 0 & 17.2 & 46 & 0 & 2 & 48 \\
\hline 5.3 & 0 & 0 & 0 & 0 & 17.4 & 91 & 8 & 24 & 123 \\
\hline 5.35 & 0 & 0 & 0 & 0 & 17.6 & 124 & 6 & 28 & 158 \\
\hline 5.4 & 0 & 0 & 0 & 0 & 17.8 & 176 & 31 & 86 & 293 \\
\hline 5.45 & 0 & 0 & 0 & 0 & 18 & 148 & 11 & 33 & 192 \\
\hline 5.5 & 0 & 0 & 0 & 0 & 18.2 & 12 & 29 & 6 & 47 \\
\hline 5.55 & 0 & 0 & 0 & 0 & 18.4 & 9 & 12 & 8 & 29 \\
\hline 5.6 & 0 & 0 & 0 & 0 & 18.6 & 21 & 49 & 58 & 128 \\
\hline 5.65 & 0 & 0 & 0 & 0 & 18.8 & 6 & 3 & 23 & 32 \\
\hline 5.7 & 0 & 0 & 0 & 0 & 19 & 4 & 3 & 2 & 9 \\
\hline 5.75 & 0 & 0 & 0 & 0 & 19.2 & 91 & 7 & 42 & 140 \\
\hline 5.8 & 0 & 0 & 0 & 0 & 19.4 & 78 & 6 & 30 & 114 \\
\hline 5.85 & 0 & 0 & 0 & 0 & 19.6 & 68 & 9 & 38 & 115 \\
\hline 5.9 & 0 & 0 & 0 & 0 & 19.8 & 67 & 0 & 25 & 92 \\
\hline 5.95 & 0 & 0 & 0 & 0 & 20 & 25 & 7 & 24 & 56 \\
\hline 6 & 0 & 0 & 0 & 0 & 20.2 & 25 & 7 & 19 & 51 \\
\hline 6.05 & 0 & 0 & 0 & 0 & 20.4 & 38 & 13 & 44 & 95 \\
\hline 6.1 & 0 & 0 & 0 & 0 & 20.6 & 39 & 78 & 66 & 183 \\
\hline 6.15 & 0 & 0 & 0 & 0 & 20.8 & 129 & 59 & 72 & 260 \\
\hline
\end{tabular}




\begin{tabular}{|c|c|c|c|c|c|c|c|c|c|}
\hline 6.2 & 1 & 0 & 0 & 1 & 21 & 139 & 86 & 97 & 322 \\
\hline 6.25 & 0 & 0 & 3 & 3 & 21.2 & 145 & 69 & 71 & 285 \\
\hline 6.3 & 0 & 0 & 8 & 8 & 21.4 & 100 & 53 & 48 & 201 \\
\hline 6.35 & 24 & 0 & 15 & 39 & 21.6 & 133 & 84 & 63 & 280 \\
\hline 6.4 & 5 & 0 & 5 & 10 & 21.8 & 96 & 43 & 41 & 180 \\
\hline 6.45 & 6 & 0 & 0 & 6 & 22 & 52 & 49 & 48 & 149 \\
\hline 6.5 & 0 & 0 & 0 & 0 & 22.2 & 18 & 47 & 64 & 129 \\
\hline 6.55 & 3 & 0 & 0 & 3 & 22.4 & 17 & 49 & 64 & 130 \\
\hline 6.6 & 0 & 0 & 0 & 0 & 22.6 & 10 & 40 & 61 & 111 \\
\hline 6.65 & 19 & 3 & 1 & 23 & 22.8 & 16 & 28 & 46 & 90 \\
\hline 6.7 & 26 & 0 & 0 & 26 & 23 & 6 & 20 & 37 & 63 \\
\hline 6.75 & 0 & 0 & 0 & 0 & 23.2 & 10 & 16 & 20 & 46 \\
\hline 6.8 & 47 & 0 & 0 & 47 & 23.4 & 10 & 47 & 18 & 75 \\
\hline 6.85 & 0 & 0 & 0 & 0 & 23.6 & 39 & 60 & 51 & 150 \\
\hline 6.9 & 0 & 0 & 0 & 0 & 23.8 & 24 & 37 & 50 & 111 \\
\hline 6.95 & 0 & 0 & 0 & 0 & 24 & 30 & 53 & 26 & 109 \\
\hline 7 & 1 & 0 & 0 & 1 & 24.2 & 80 & 36 & 24 & 140 \\
\hline 7.05 & 15 & 0 & 3 & 18 & 24.4 & 13 & 28 & 32 & 73 \\
\hline 7.1 & 6 & 0 & 0 & 6 & 24.6 & 18 & 51 & 31 & 100 \\
\hline 7.15 & 2 & 0 & 1 & 3 & 24.8 & 11 & 40 & 44 & 95 \\
\hline 7.2 & 0 & 0 & 0 & 0 & 25 & 2 & 51 & 44 & 97 \\
\hline 7.25 & 0 & 0 & 0 & 0 & 25.2 & 3 & 37 & 30 & 70 \\
\hline 7.3 & 0 & 0 & 0 & 0 & 25.4 & 11 & 54 & 66 & 131 \\
\hline 7.35 & 0 & 0 & 0 & 0 & 25.6 & 30 & 35 & 68 & 133 \\
\hline 7.4 & 0 & 0 & 0 & 0 & 25.8 & 11 & 37 & 60 & 108 \\
\hline 7.45 & 0 & 0 & 0 & 0 & 26 & 32 & 55 & 47 & 134 \\
\hline 7.5 & 2 & 0 & 0 & 2 & 26.2 & 40 & 40 & 52 & 132 \\
\hline
\end{tabular}




\begin{tabular}{|c|c|c|c|c|c|c|c|c|c|}
\hline 7.55 & 14 & 0 & 0 & 14 & 26.4 & 4 & 52 & 27 & 83 \\
\hline 7.6 & 36 & 0 & 0 & 36 & 26.6 & 6 & 52 & 34 & 92 \\
\hline 7.65 & 5 & 0 & 0 & 5 & 26.8 & 4 & 43 & 16 & 63 \\
\hline 7.7 & 8 & 0 & 0 & 8 & 27 & 8 & 47 & 11 & 66 \\
\hline 7.75 & 1 & 0 & 0 & 1 & 27.2 & 9 & 99 & 36 & 144 \\
\hline 7.8 & 3 & 0 & 0 & 3 & 27.4 & 7 & 71 & 56 & 134 \\
\hline 7.85 & 0 & 0 & 0 & 0 & 27.6 & 7 & 31 & 40 & 78 \\
\hline 7.9 & 105 & 4 & 0 & 109 & 27.8 & 30 & 26 & 38 & 94 \\
\hline 7.95 & 42 & 0 & 0 & 42 & 28 & 2 & 9 & 10 & 21 \\
\hline 8 & 30 & 0 & 0 & 30 & 28.2 & 4 & 75 & 27 & 106 \\
\hline 8.05 & 15 & 0 & 0 & 15 & 28.4 & 10 & 75 & 23 & 108 \\
\hline 8.1 & 12 & 0 & 0 & 12 & 28.6 & 0 & 2 & 1 & 3 \\
\hline 8.15 & 24 & 0 & 0 & 24 & 28.8 & 5 & 37 & 14 & 56 \\
\hline 8.2 & 61 & 3 & 0 & 64 & 29 & 1 & 13 & 8 & 22 \\
\hline 8.25 & 6 & 0 & 0 & 6 & 29.2 & 0 & 3 & 2 & 5 \\
\hline 8.3 & 17 & 0 & 0 & 17 & 29.4 & 0 & 2 & 4 & 6 \\
\hline 8.35 & 13 & 1 & 1 & 15 & 29.6 & 0 & 8 & 1 & 9 \\
\hline 8.4 & 30 & 0 & 0 & 30 & 29.8 & 0 & 0 & 0 & 0 \\
\hline 8.45 & 52 & 4 & 2 & 58 & 30 & 0 & 0 & 0 & 0 \\
\hline 8.5 & 49 & 1 & 0 & 50 & 30.2 & 12 & 35 & 35 & 82 \\
\hline 8.55 & 147 & 2 & 0 & 149 & 30.4 & 9 & 39 & 50 & 98 \\
\hline 8.6 & 97 & 3 & 0 & 100 & 30.6 & 5 & 54 & 32 & 91 \\
\hline 8.65 & 85 & 0 & 0 & 85 & 30.8 & 3 & 35 & 35 & 73 \\
\hline 8.7 & 103 & 4 & 0 & 107 & 31 & 3 & 56 & 50 & 109 \\
\hline 8.75 & 40 & 10 & 15 & 65 & 31.2 & 4 & 30 & 50 & 84 \\
\hline 8.8 & 88 & 13 & 37 & 138 & 31.4 & 15 & 50 & 49 & 114 \\
\hline 8.85 & 31 & 4 & 9 & 44 & 31.6 & 19 & 41 & 50 & 110 \\
\hline
\end{tabular}




\begin{tabular}{|c|c|c|c|c|c|c|c|c|c|}
\hline 8.9 & 0 & 0 & 0 & 0 & 31.8 & 4 & 34 & 17 & 55 \\
\hline 8.95 & 0 & 0 & 0 & 0 & 32 & 0 & 0 & 0 & 0 \\
\hline 9 & 150 & 26 & 27 & 203 & 32.2 & 0 & 0 & 0 & 0 \\
\hline 9.1 & 130 & 10 & 10 & 150 & 32.4 & 1 & 38 & 11 & 50 \\
\hline 9.2 & 152 & 0 & 3 & 155 & 32.6 & 0 & 62 & 16 & 78 \\
\hline 9.3 & 111 & 14 & 1 & 126 & 32.8 & 1 & 84 & 16 & 101 \\
\hline 9.4 & 58 & 18 & 0 & 76 & 33 & 0 & 17 & 8 & 25 \\
\hline 9.5 & 105 & 17 & 0 & 122 & 33.2 & 0 & 17 & 20 & 37 \\
\hline 9.6 & 44 & 5 & 0 & 49 & 33.4 & 8 & 31 & 12 & 51 \\
\hline 9.7 & 5 & 0 & 0 & 5 & 33.6 & 0 & 33 & 8 & 41 \\
\hline 9.8 & 0 & 0 & 0 & 0 & 33.8 & 6 & 103 & 3 & 112 \\
\hline 9.9 & 6 & 0 & 0 & 6 & 34 & 10 & 43 & 9 & 62 \\
\hline 10 & 10 & 0 & 0 & 10 & 34.2 & 0 & 51 & 7 & 58 \\
\hline 10.1 & 17 & 7 & 0 & 24 & 34.4 & 3 & 43 & 13 & 59 \\
\hline 10.2 & 117 & 15 & 0 & 132 & 34.6 & 2 & 47 & 9 & 58 \\
\hline 10.3 & 300 & 45 & 0 & 345 & 34.8 & 2 & 34 & 11 & 47 \\
\hline 10.4 & 135 & 41 & 6 & 182 & 35 & 5 & 18 & 9 & 32 \\
\hline 10.5 & 86 & 24 & 9 & 119 & 35.2 & 2 & 28 & 5 & 35 \\
\hline 10.6 & 137 & 28 & 47 & 212 & 35.4 & 0 & 0 & 0 & 0 \\
\hline 10.7 & 108 & 5 & 12 & 125 & 35.6 & 47 & 81 & 39 & 167 \\
\hline 10.8 & 115 & 3 & 8 & 126 & 35.8 & 24 & 113 & 16 & 153 \\
\hline 10.9 & 211 & 11 & 9 & 231 & 36 & 25 & 109 & 28 & 162 \\
\hline 11 & 119 & 5 & 3 & 127 & 36.2 & 18 & 65 & 15 & 98 \\
\hline 11.1 & 31 & 7 & 1 & 39 & 36.4 & 5 & 51 & 22 & 78 \\
\hline 11.2 & 45 & 20 & 3 & 68 & 36.6 & 4 & 47 & 14 & 65 \\
\hline 11.3 & 27 & 8 & 3 & 38 & 36.8 & 7 & 34 & 14 & 55 \\
\hline 11.4 & 27 & 12 & 2 & 41 & 37 & 2 & 11 & 4 & 17 \\
\hline
\end{tabular}




\begin{tabular}{|c|c|c|c|c|c|c|c|c|c|}
\hline 11.5 & 10 & 0 & 0 & 10 & 37.2 & 5 & 43 & 5 & 53 \\
\hline 11.6 & 80 & 0 & 0 & 80 & 37.4 & 23 & 73 & 17 & 113 \\
\hline 11.7 & 183 & 6 & 3 & 192 & 37.6 & 27 & 77 & 27 & 131 \\
\hline 11.8 & 308 & 25 & 2 & 335 & 37.8 & 6 & 63 & 16 & 85 \\
\hline 11.9 & 82 & 40 & 0 & 122 & 38 & 22 & 95 & 27 & 144 \\
\hline 12 & 100 & 180 & 3 & 283 & 38.2 & 11 & 59 & 18 & 88 \\
\hline 12.1 & 70 & 248 & 3 & 321 & 38.4 & 9 & 19 & 14 & 42 \\
\hline 12.2 & 59 & 163 & 7 & 229 & 38.6 & 1 & 14 & 1 & 16 \\
\hline 12.3 & 60 & 165 & 7 & 232 & 38.8 & 13 & 48 & 17 & 78 \\
\hline 12.4 & 47 & 49 & 2 & 98 & 39 & 13 & 23 & 11 & 47 \\
\hline 12.5 & 192 & 63 & 7 & 262 & 39.2 & 19 & 36 & 18 & 73 \\
\hline 12.6 & 72 & 64 & 1 & 137 & 39.4 & 8 & 24 & 13 & 45 \\
\hline 12.7 & 32 & 21 & 0 & 53 & 39.6 & 1 & 9 & 3 & 13 \\
\hline 12.8 & 15 & 32 & 0 & 47 & 39.8 & 4 & 17 & 8 & 29 \\
\hline 12.9 & 23 & 21 & 3 & 47 & 40 & 2 & 7 & 1 & 10 \\
\hline 13 & 22 & 75 & 2 & 99 & 40.2 & 3 & 38 & 22 & 63 \\
\hline
\end{tabular}


Table 2: Benthic Foraminifera Raw Data

\begin{tabular}{|c|c|c|c|c|c|c|c|c|c|}
\hline \multirow{2}{*}{$\begin{array}{l}\text { Sample } \\
\text { Depth } \\
\text { (Meters) }\end{array}$} & \multicolumn{4}{|c|}{ Benthic Morphotypes } & \multirow{2}{*}{$\begin{array}{c}\text { Sample } \\
\text { Depth } \\
\text { (Meters) }\end{array}$} & \multicolumn{4}{|c|}{ Benthic Morphotypes } \\
\hline & Neobulimina & Gavelinella & Agglutinates & $\begin{array}{c}\text { Benthic } \\
\text { Total }\end{array}$ & & Neobulimina & Gavelinella & Agglutinates & $\begin{array}{c}\text { Benthic } \\
\text { Total } \\
\end{array}$ \\
\hline 0 & 0 & 0 & 0 & 0 & 13.1 & 44 & 86 & 0 & 130 \\
\hline 0.2 & 0 & 0 & 0 & 0 & 13.2 & 82 & 18 & 0 & 100 \\
\hline 0.4 & 0 & 0 & 0 & 0 & 13.3 & 148 & 20 & 0 & 168 \\
\hline 0.6 & 0 & 0 & 0 & 0 & 13.4 & 135 & 74 & 0 & 209 \\
\hline 0.8 & 0 & 0 & 0 & 0 & 13.5 & 91 & 63 & 2 & 156 \\
\hline 1 & 0 & 0 & 0 & 0 & 13.6 & 28 & 15 & 0 & 43 \\
\hline 1.2 & 0 & 0 & 0 & 0 & 13.7 & 0 & 6 & 12 & 18 \\
\hline 1.4 & 0 & 0 & 15 & 15 & 13.8 & 22 & 2 & 8 & 32 \\
\hline 1.6 & 0 & 0 & 21 & 21 & 13.9 & 64 & 18 & 28 & 110 \\
\hline 1.8 & 0 & 0 & 11 & 11 & 14 & 17 & 7 & 11 & 35 \\
\hline 2 & 0 & 0 & 4 & 4 & 14.1 & 12 & 40 & 12 & 64 \\
\hline 2.2 & 0 & 0 & 45 & 45 & 14.2 & 0 & 11 & 0 & 11 \\
\hline 2.4 & 0 & 0 & 31 & 31 & 14.3 & 5 & 5 & 10 & 20 \\
\hline 2.6 & 0 & 0 & 16 & 16 & 14.4 & 5 & 18 & 10 & 33 \\
\hline 2.8 & 0 & 0 & 19 & 19 & 14.5 & 0 & 0 & 0 & 0 \\
\hline 3 & 0 & 0 & 13 & 13 & 14.6 & 0 & 0 & 0 & 0 \\
\hline 3.2 & 0 & 0 & 0 & 0 & 14.7 & 0 & 0 & 0 & 0 \\
\hline 3.4 & 0 & 0 & 0 & 0 & 14.8 & 19 & 54 & 0 & 73 \\
\hline 3.6 & 0 & 0 & 0 & 0 & 14.9 & 0 & 0 & 0 & 0 \\
\hline 3.8 & 0 & 0 & 0 & 0 & 15 & 75 & 60 & 0 & 135 \\
\hline 4 & 0 & 0 & 0 & 0 & 15.2 & 24 & 48 & 0 & 72 \\
\hline 4.2 & 0 & 0 & 0 & 0 & 15.4 & 13 & 28 & 0 & 41 \\
\hline
\end{tabular}




\begin{tabular}{|c|c|c|c|c|c|c|c|c|c|}
\hline 4.4 & 0 & 0 & 0 & 0 & 15.6 & 11 & 46 & 0 & 57 \\
\hline 4.6 & 0 & 0 & 0 & 0 & 15.8 & 8 & 21 & 0 & 29 \\
\hline 4.8 & 0 & 0 & 0 & 0 & 16 & 13 & 38 & 0 & 51 \\
\hline 5 & 0 & 0 & 0 & 0 & 16.2 & 6 & 34 & 0 & 40 \\
\hline 5.05 & 0 & 0 & 0 & 0 & 16.4 & 24 & 17 & 8 & 49 \\
\hline 5.1 & 0 & 0 & 0 & 0 & 16.6 & 17 & 36 & 0 & 53 \\
\hline 5.15 & 0 & 0 & 0 & 0 & 16.8 & 249 & 55 & 0 & 304 \\
\hline 5.2 & 0 & 0 & 0 & 0 & 17 & 317 & 13 & 0 & 330 \\
\hline 5.25 & 0 & 0 & 0 & 0 & 17.2 & 280 & 7 & 2 & 289 \\
\hline 5.3 & 0 & 0 & 0 & 0 & 17.4 & 247 & 8 & 2 & 257 \\
\hline 5.35 & 0 & 0 & 0 & 0 & 17.6 & 149 & 11 & 0 & 160 \\
\hline 5.4 & 0 & 0 & 0 & 0 & 17.8 & 163 & 34 & 0 & 197 \\
\hline 5.45 & 0 & 0 & 0 & 0 & 18 & 159 & 8 & 2 & 169 \\
\hline 5.5 & 0 & 0 & 0 & 0 & 18.2 & 340 & 60 & 18 & 418 \\
\hline 5.55 & 0 & 0 & 0 & 0 & 18.4 & 320 & 37 & 11 & 368 \\
\hline 5.6 & 0 & 0 & 0 & 0 & 18.6 & 367 & 22 & 5 & 394 \\
\hline 5.65 & 0 & 0 & 0 & 0 & 18.8 & 330 & 43 & 11 & 384 \\
\hline 5.7 & 0 & 0 & 0 & 0 & 19 & 323 & 18 & 6 & 347 \\
\hline 5.75 & 0 & 0 & 0 & 0 & 19.2 & 325 & 37 & 1 & 363 \\
\hline 5.8 & 0 & 0 & 0 & 0 & 19.4 & 207 & 22 & 4 & 233 \\
\hline 5.85 & 0 & 0 & 0 & 0 & 19.6 & 300 & 32 & 4 & 336 \\
\hline 5.9 & 0 & 0 & 0 & 0 & 19.8 & 264 & 25 & 9 & 298 \\
\hline 5.95 & 0 & 0 & 0 & 0 & 20 & 323 & 29 & 6 & 358 \\
\hline 6 & 0 & 0 & 0 & 0 & 20.2 & 329 & 19 & 2 & 350 \\
\hline 6.05 & 0 & 0 & 0 & 0 & 20.4 & 376 & 11 & 1 & 388 \\
\hline 6.1 & 0 & 0 & 0 & 0 & 20.6 & 221 & 16 & 0 & 237 \\
\hline 6.15 & 0 & 1 & 0 & 1 & 20.8 & 167 & 18 & 0 & 185 \\
\hline
\end{tabular}




\begin{tabular}{|c|c|c|c|c|c|c|c|c|c|}
\hline 6.2 & 89 & 2 & 0 & 91 & 21 & 209 & 31 & 0 & 240 \\
\hline 6.25 & 332 & 0 & 0 & 332 & 21.2 & 262 & 34 & 2 & 298 \\
\hline 6.3 & 292 & 0 & 0 & 292 & 21.4 & 232 & 16 & 3 & 251 \\
\hline 6.35 & 256 & 0 & 0 & 256 & 21.6 & 215 & 38 & 2 & 255 \\
\hline 6.4 & 57 & 0 & 0 & 57 & 21.8 & 176 & 15 & 0 & 191 \\
\hline 6.45 & 12 & 0 & 0 & 12 & 22 & 162 & 26 & 0 & 188 \\
\hline 6.5 & 0 & 0 & 0 & 0 & 22.2 & 165 & 18 & 1 & 184 \\
\hline 6.55 & 3 & 0 & 0 & 3 & 22.4 & 193 & 19 & 0 & 212 \\
\hline 6.6 & 0 & 0 & 0 & 0 & 22.6 & 236 & 20 & 0 & 256 \\
\hline 6.65 & 5 & 0 & 0 & 5 & 22.8 & 262 & 46 & 1 & 309 \\
\hline 6.7 & 4 & 0 & 0 & 4 & 23 & 215 & 38 & 0 & 253 \\
\hline 6.75 & 0 & 0 & 0 & 0 & 23.2 & 237 & 35 & 1 & 273 \\
\hline 6.8 & 13 & 0 & 0 & 13 & 23.4 & 225 & 70 & 1 & 296 \\
\hline 6.85 & 2 & 0 & 0 & 2 & 23.6 & 139 & 77 & 0 & 216 \\
\hline 6.9 & 0 & 0 & 0 & 0 & 23.8 & 213 & 58 & 1 & 272 \\
\hline 6.95 & 0 & 0 & 0 & 0 & 24 & 246 & 36 & 1 & 283 \\
\hline 7 & 0 & 0 & 0 & 0 & 24.2 & 213 & 43 & 0 & 256 \\
\hline 7.05 & 0 & 2 & 2 & 4 & 24.4 & 201 & 26 & 0 & 227 \\
\hline 7.1 & 0 & 1 & 0 & 1 & 24.6 & 158 & 42 & 0 & 200 \\
\hline 7.15 & 0 & 0 & 0 & 0 & 24.8 & 257 & 43 & 2 & 302 \\
\hline 7.2 & 0 & 0 & 0 & 0 & 25 & 217 & 64 & 0 & 281 \\
\hline 7.25 & 0 & 0 & 0 & 0 & 25.2 & 213 & 11 & 0 & 224 \\
\hline 7.3 & 0 & 0 & 0 & 0 & 25.4 & 231 & 26 & 1 & 258 \\
\hline 7.35 & 0 & 0 & 0 & 0 & 25.6 & 187 & 66 & 3 & 256 \\
\hline 7.4 & 0 & 0 & 0 & 0 & 25.8 & 118 & 83 & 0 & 201 \\
\hline 7.45 & 0 & 0 & 0 & 0 & 26 & 136 & 30 & 0 & 166 \\
\hline 7.5 & 0 & 0 & 0 & 0 & 26.2 & 139 & 32 & 4 & 175 \\
\hline
\end{tabular}




\begin{tabular}{|c|c|c|c|c|c|c|c|c|c|}
\hline 7.55 & 0 & 0 & 0 & 0 & 26.4 & 176 & 44 & 1 & 221 \\
\hline 7.6 & 0 & 0 & 0 & 0 & 26.6 & 191 & 24 & 3 & 218 \\
\hline 7.65 & 2 & 1 & 1 & 4 & 26.8 & 241 & 22 & 7 & 270 \\
\hline 7.7 & 1 & 0 & 0 & 1 & 27 & 234 & 2 & 0 & 236 \\
\hline 7.75 & 0 & 0 & 0 & 0 & 27.2 & 133 & 63 & 0 & 196 \\
\hline 7.8 & 0 & 0 & 0 & 0 & 27.4 & 120 & 46 & 2 & 168 \\
\hline 7.85 & 0 & 0 & 0 & 0 & 27.6 & 202 & 20 & 3 & 225 \\
\hline 7.9 & 15 & 1 & 0 & 16 & 27.8 & 180 & 26 & 1 & 207 \\
\hline 7.95 & 0 & 0 & 0 & 0 & 28 & 71 & 15 & 0 & 86 \\
\hline 8 & 12 & 0 & 0 & 12 & 28.2 & 147 & 61 & 3 & 211 \\
\hline 8.05 & 5 & 0 & 0 & 5 & 28.4 & 158 & 40 & 0 & 198 \\
\hline 8.1 & 12 & 1 & 0 & 13 & 28.6 & 88 & 14 & 5 & 107 \\
\hline 8.15 & 21 & 0 & 0 & 21 & 28.8 & 209 & 34 & 1 & 244 \\
\hline 8.2 & 29 & 0 & 0 & 29 & 29 & 207 & 37 & 5 & 249 \\
\hline 8.25 & 12 & 1 & 0 & 13 & 29.2 & 35 & 7 & 4 & 46 \\
\hline 8.3 & 9 & 0 & 0 & 9 & 29.4 & 70 & 13 & 5 & 88 \\
\hline 8.35 & 10 & 0 & 0 & 10 & 29.6 & 32 & 19 & 2 & 53 \\
\hline 8.4 & 39 & 2 & 1 & 42 & 29.8 & 0 & 0 & 0 & 0 \\
\hline 8.45 & 43 & 4 & 0 & 47 & 30 & 0 & 0 & 0 & 0 \\
\hline 8.5 & 36 & 30 & 18 & 84 & 30.2 & 144 & 16 & 0 & 160 \\
\hline 8.55 & 153 & 0 & 0 & 153 & 30.4 & 212 & 23 & 1 & 236 \\
\hline 8.6 & 158 & 1 & 0 & 159 & 30.6 & 236 & 63 & 0 & 299 \\
\hline 8.65 & 218 & 2 & 0 & 220 & 30.8 & 228 & 14 & 0 & 242 \\
\hline 8.7 & 163 & 1 & 0 & 164 & 31 & 177 & 45 & 0 & 222 \\
\hline 8.75 & 33 & 2 & 0 & 35 & 31.2 & 217 & 75 & 0 & 292 \\
\hline 8.8 & 94 & 17 & 0 & 111 & 31.4 & 148 & 72 & 0 & 220 \\
\hline 8.85 & 52 & 10 & 0 & 62 & 31.6 & 215 & 54 & 0 & 269 \\
\hline
\end{tabular}




\begin{tabular}{|c|c|c|c|c|c|c|c|c|c|}
\hline 8.9 & 0 & 0 & 0 & 0 & 31.8 & 226 & 19 & 0 & 245 \\
\hline 8.95 & 0 & 0 & 0 & 0 & 32 & 0 & 0 & 0 & 0 \\
\hline 9 & 68 & 35 & 0 & 103 & 32.2 & 0 & 0 & 0 & 0 \\
\hline 9.1 & 60 & 17 & 0 & 77 & 32.4 & 291 & 27 & 0 & 318 \\
\hline 9.2 & 74 & 16 & 0 & 90 & 32.6 & 310 & 14 & 0 & 324 \\
\hline 9.3 & 73 & 8 & 1 & 82 & 32.8 & 248 & 24 & 0 & 272 \\
\hline 9.4 & 102 & 19 & 0 & 121 & 33 & 211 & 64 & 0 & 275 \\
\hline 9.5 & 134 & 10 & 0 & 144 & 33.2 & 229 & 44 & 0 & 273 \\
\hline 9.6 & 234 & 7 & 0 & 241 & 33.4 & 252 & 38 & 0 & 290 \\
\hline 9.7 & 5 & 0 & 0 & 5 & 33.6 & 173 & 86 & 0 & 259 \\
\hline 9.8 & 0 & 0 & 0 & 0 & 33.8 & 167 & 23 & 0 & 190 \\
\hline 9.9 & 4 & 0 & 0 & 4 & 34 & 282 & 28 & 0 & 310 \\
\hline 10 & 160 & 36 & 18 & 214 & 34.2 & 223 & 25 & 0 & 248 \\
\hline 10.1 & 110 & 56 & 46 & 212 & 34.4 & 209 & 50 & 0 & 259 \\
\hline 10.2 & 119 & 88 & 67 & 274 & 34.6 & 220 & 23 & 0 & 243 \\
\hline 10.3 & 165 & 105 & 20 & 290 & 34.8 & 201 & 53 & 0 & 254 \\
\hline 10.4 & 336 & 85 & 14 & 435 & 35 & 231 & 39 & 0 & 270 \\
\hline 10.5 & 318 & 106 & 7 & 431 & 35.2 & 302 & 50 & 0 & 352 \\
\hline 10.6 & 209 & 83 & 1 & 293 & 35.4 & 0 & 0 & 0 & 0 \\
\hline 10.7 & 62 & 101 & 0 & 163 & 35.6 & 162 & 31 & 0 & 193 \\
\hline 10.8 & 137 & 83 & 0 & 220 & 35.8 & 136 & 18 & 0 & 154 \\
\hline 10.9 & 266 & 104 & 4 & 374 & 36 & 219 & 21 & 0 & 240 \\
\hline 11 & 158 & 45 & 0 & 203 & 36.2 & 242 & 36 & 0 & 278 \\
\hline 11.1 & 171 & 42 & 0 & 213 & 36.4 & 169 & 59 & 0 & 228 \\
\hline 11.2 & 241 & 63 & 0 & 304 & 36.6 & 208 & 37 & 0 & 245 \\
\hline 11.3 & 260 & 53 & 0 & 313 & 36.8 & 158 & 43 & 0 & 201 \\
\hline 11.4 & 175 & 32 & 0 & 207 & 37 & 96 & 20 & 0 & 116 \\
\hline
\end{tabular}




\begin{tabular}{|c|c|c|c|c|c|c|c|c|c|}
\hline 11.5 & 0 & 3 & 0 & 3 & 37.2 & 154 & 9 & 0 & 163 \\
\hline 11.6 & 0 & 30 & 0 & 30 & 37.4 & 185 & 14 & 0 & 199 \\
\hline 11.7 & 20 & 78 & 0 & 98 & 37.6 & 151 & 21 & 0 & 172 \\
\hline 11.8 & 11 & 61 & 0 & 72 & 37.8 & 204 & 16 & 0 & 220 \\
\hline 11.9 & 20 & 72 & 0 & 92 & 38 & 170 & 18 & 0 & 188 \\
\hline 12 & 77 & 105 & 0 & 182 & 38.2 & 199 & 16 & 0 & 215 \\
\hline 12.1 & 81 & 145 & 0 & 226 & 38.4 & 111 & 14 & 0 & 125 \\
\hline 12.2 & 75 & 81 & 0 & 156 & 38.6 & 114 & 12 & 0 & 126 \\
\hline 12.3 & 56 & 64 & 0 & 120 & 38.8 & 198 & 24 & 0 & 222 \\
\hline 12.4 & 56 & 101 & 0 & 157 & 39 & 143 & 18 & 0 & 161 \\
\hline 12.5 & 118 & 64 & 0 & 182 & 39.2 & 223 & 40 & 0 & 263 \\
\hline 12.6 & 112 & 39 & 0 & 151 & 39.4 & 108 & 33 & 0 & 141 \\
\hline 12.7 & 67 & 46 & 0 & 113 & 39.6 & 144 & 14 & 0 & 158 \\
\hline 12.8 & 69 & 60 & 0 & 129 & 39.8 & 121 & 22 & 0 & 143 \\
\hline 12.9 & 70 & 61 & 0 & 131 & 40 & 215 & 13 & 0 & 228 \\
\hline 13 & 60 & 112 & 0 & 172 & 40.2 & 66 & 19 & 0 & 85 \\
\hline
\end{tabular}


APPENDIX B

FIGURES 


\section{Paleogeography of the Late Cretaceous}

\section{(Late Cenomanian-Early Turonian) Western Interior Seaway}

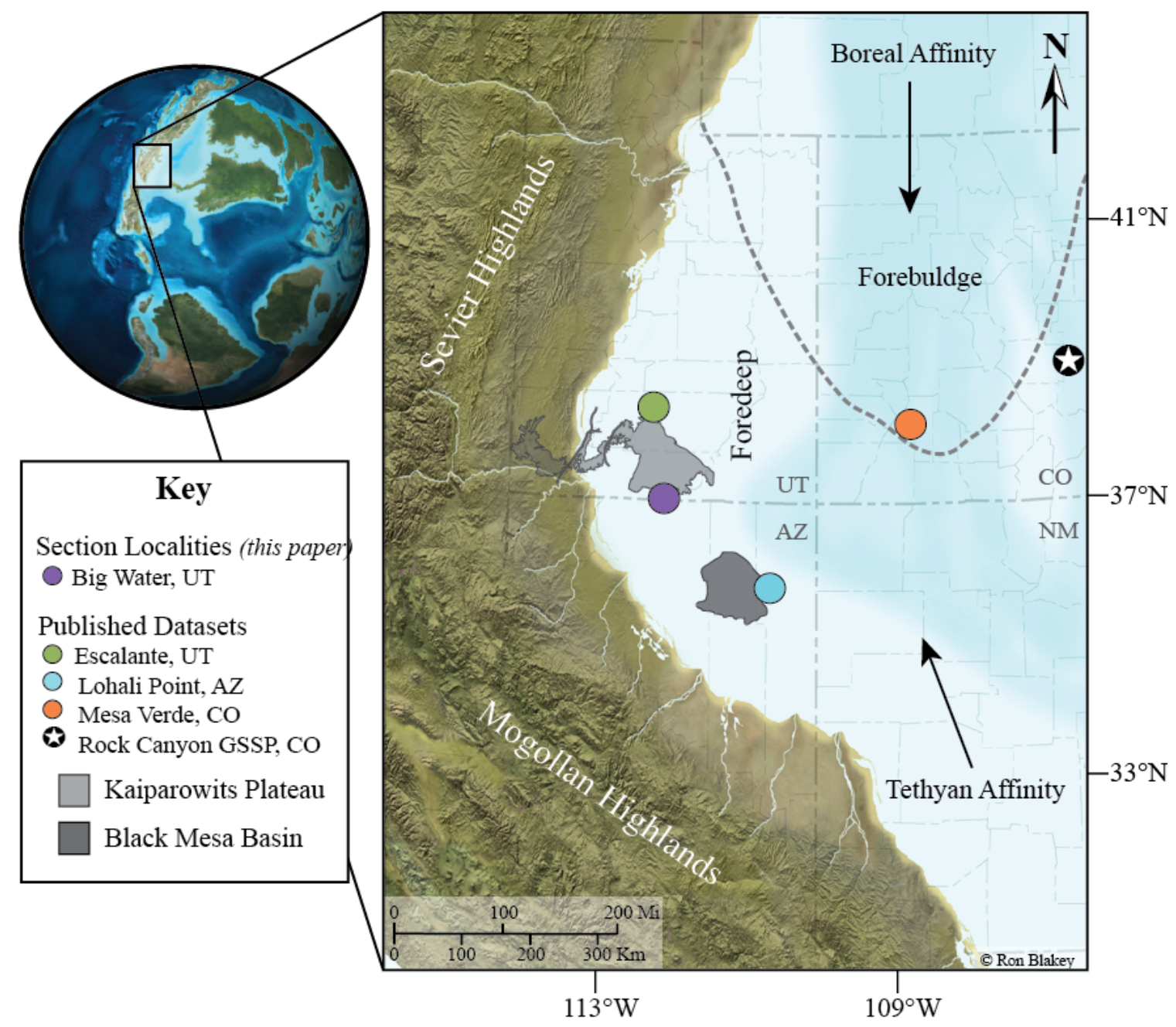

Figure 1: Paleogeographic reconstruction of the Colorado Plateau from the Late Cretaceous. Paleogeographic map indicates that the southwestern mid-continent U.S. lay at approximately $40-30^{\circ} \mathrm{N}$ and $114-108^{\circ} \mathrm{W}$ (Ziegler et al., 1987; McCabe and Parrish, 1992). To the west of the middle-Turonian shoreline, the Sevier and Mogollan Highlands provided significant paleotopographic highs (Parrish, 1993). To the east, a relatively shallow seaway extended from Alaska to Mexico connecting the Boreal Sea and Tethys Ocean (Kauffman, 1977, 1984). The map depicts site locations and their relative position to the GSSP section at Rock Canyon, CO. 


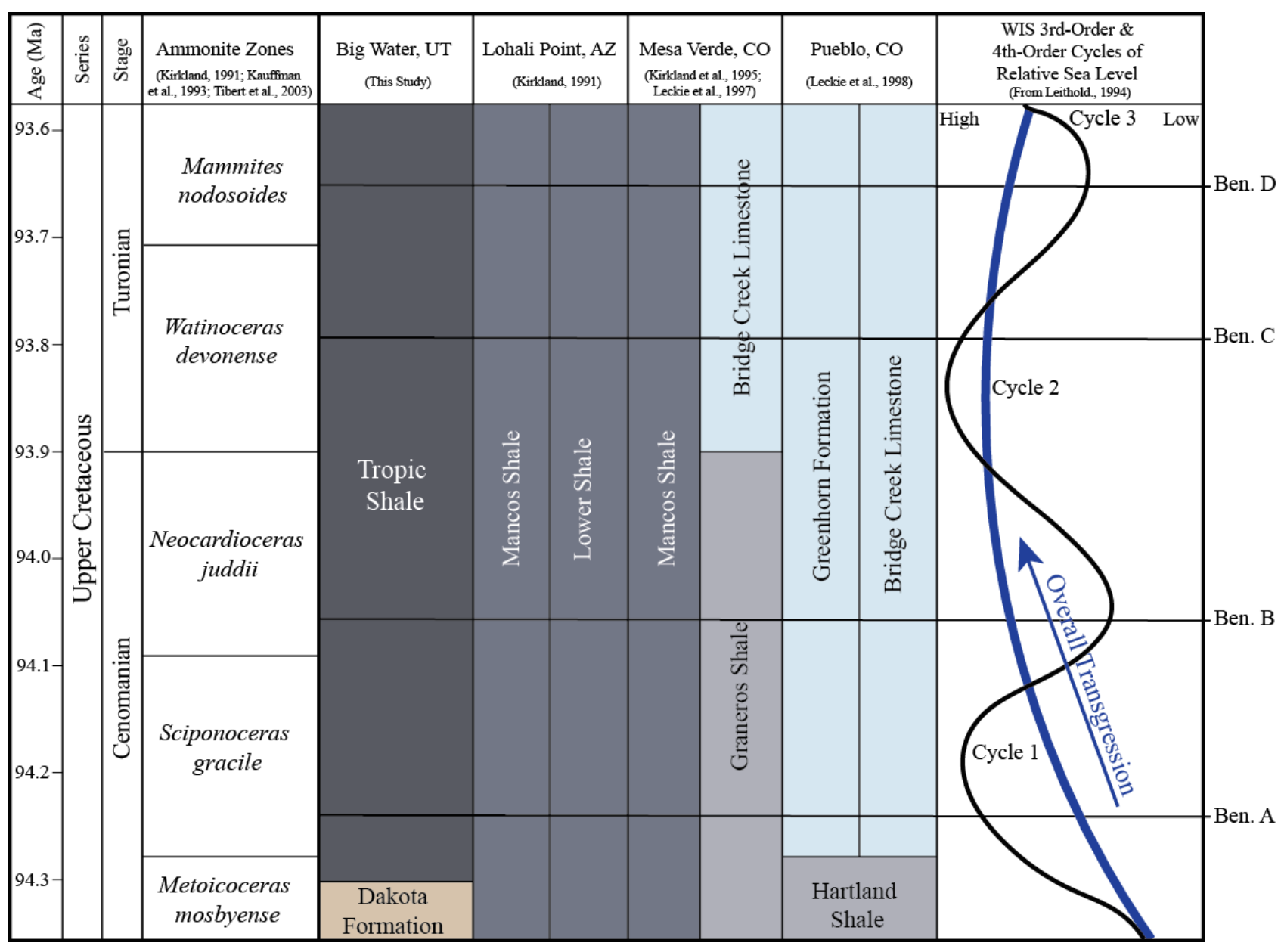

Figure 2: Chronostratigraphic correlations depicted between southern Utah and the Cenomanian-Turonian GSSP near Pueblo, Colorado. Third-order and fourth-order relative sea level cycles are recognized across the Colorado Plateau based on Leithold (1994). Correlation and stage boundary based on our own data, as well as figures and descriptions from published datasets (see figure for references). Bentonites A, B, C, and D are noted from Elder (1988, 1991). Ages based on Meyers et al. (2012a). 


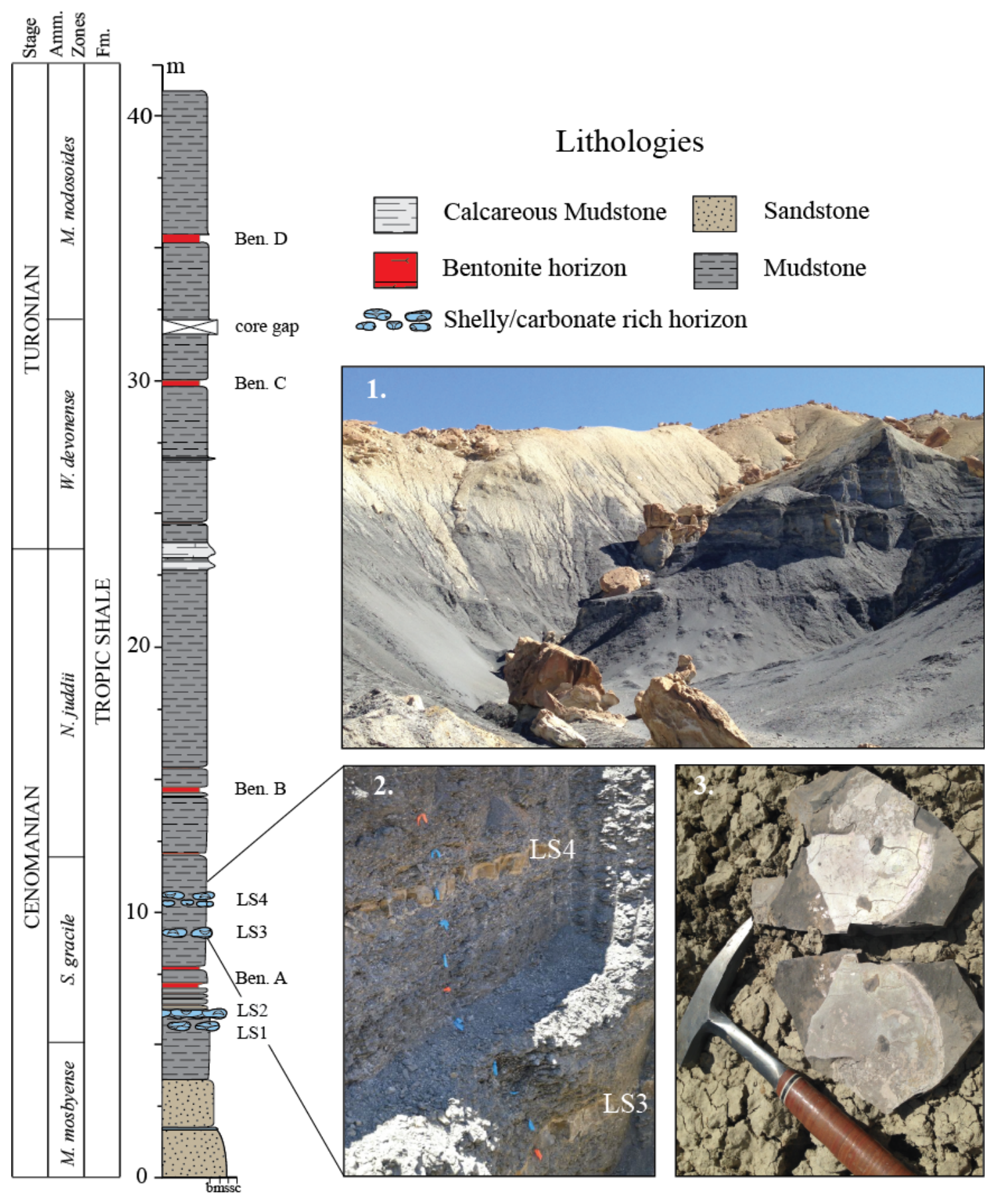

Figure 3: Stratigraphic section near Big Water, Utah. Tropic Shale consists primarily of calcareous shale and mudstone representing muddy prodeltaic depositional environments of the western margin of the seaway. (1.) Tropic Shale forms broad undulating flats with gentle slopes across the field area increasing gradient up-section. (2.) Limestone beds 3 and 4 depicted. (3.) Note aragonite composition (shiny 'mother of pearl') of ammonite recovered from outcrop. 


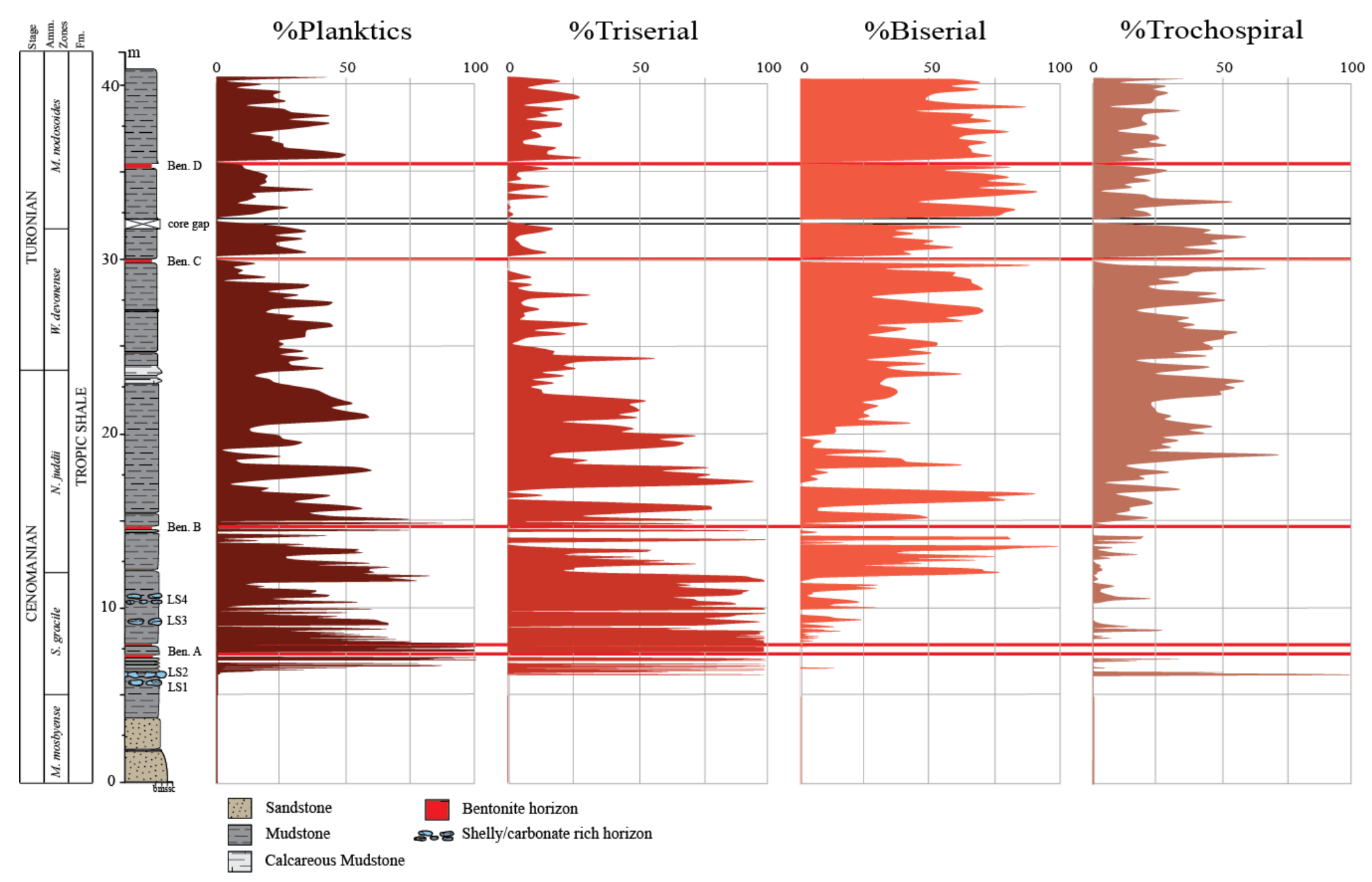

Figure 4: Planktic foraminiferal assemblage data from the Big Water, Utah. Includes stratigraphic outcrop description, \%Planktics (planktic/benthic ratio), \%Triserial (Guembelitria cenomana), \%Biserial (Heterohelix spp.), and \%Trochospiral (Hedbergella spp. and Whiteinella spp.). Note the position of the four main bentonite A-D (red lines). 


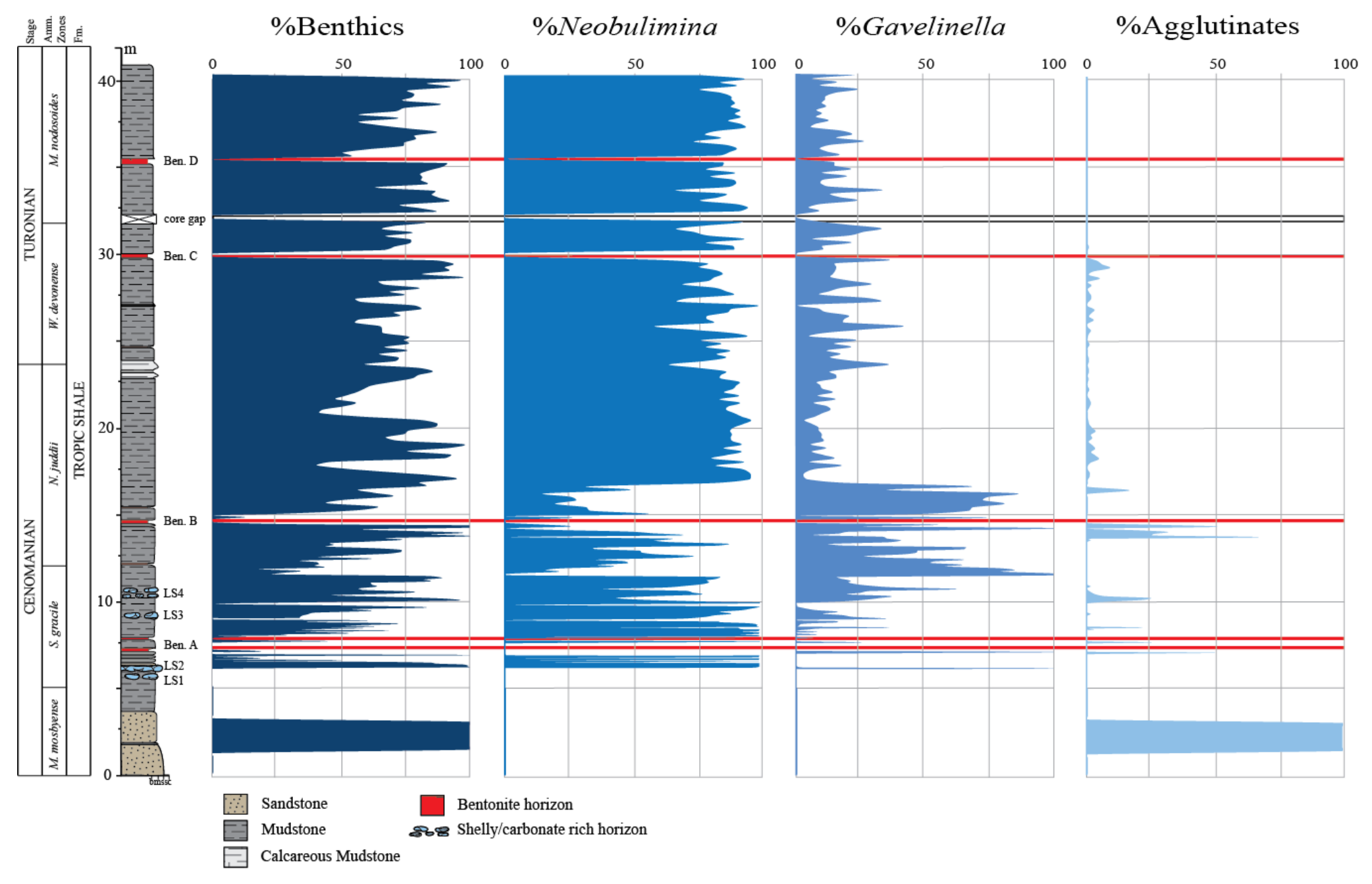

Figure 5: Benthic foraminiferal assemblage data from the Big Water, Utah. Includes stratigraphic outcrop description, \%benthics (benthic/total foraminifera), \%Neobulimina albertensis, \%Gavelinella dakotensis, and \%Agglutinates. Note the position of the four major bentonite A-D (red lines). 


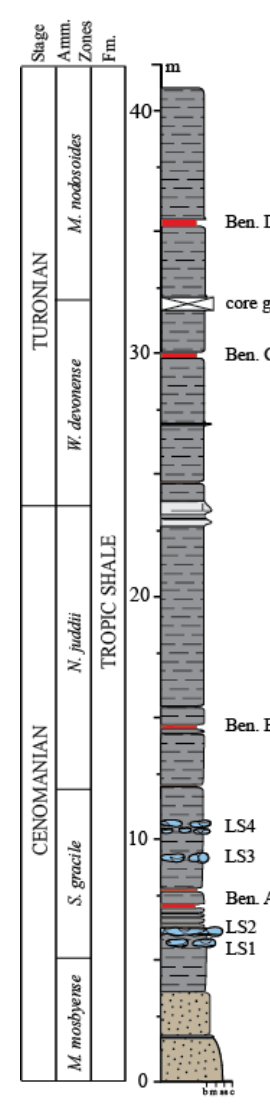

$\%$ Sinistral Trochospiral spp.

$\delta^{13} \mathrm{C}_{\text {org }}$

$\delta^{18} \mathrm{O}_{\text {carb }}$
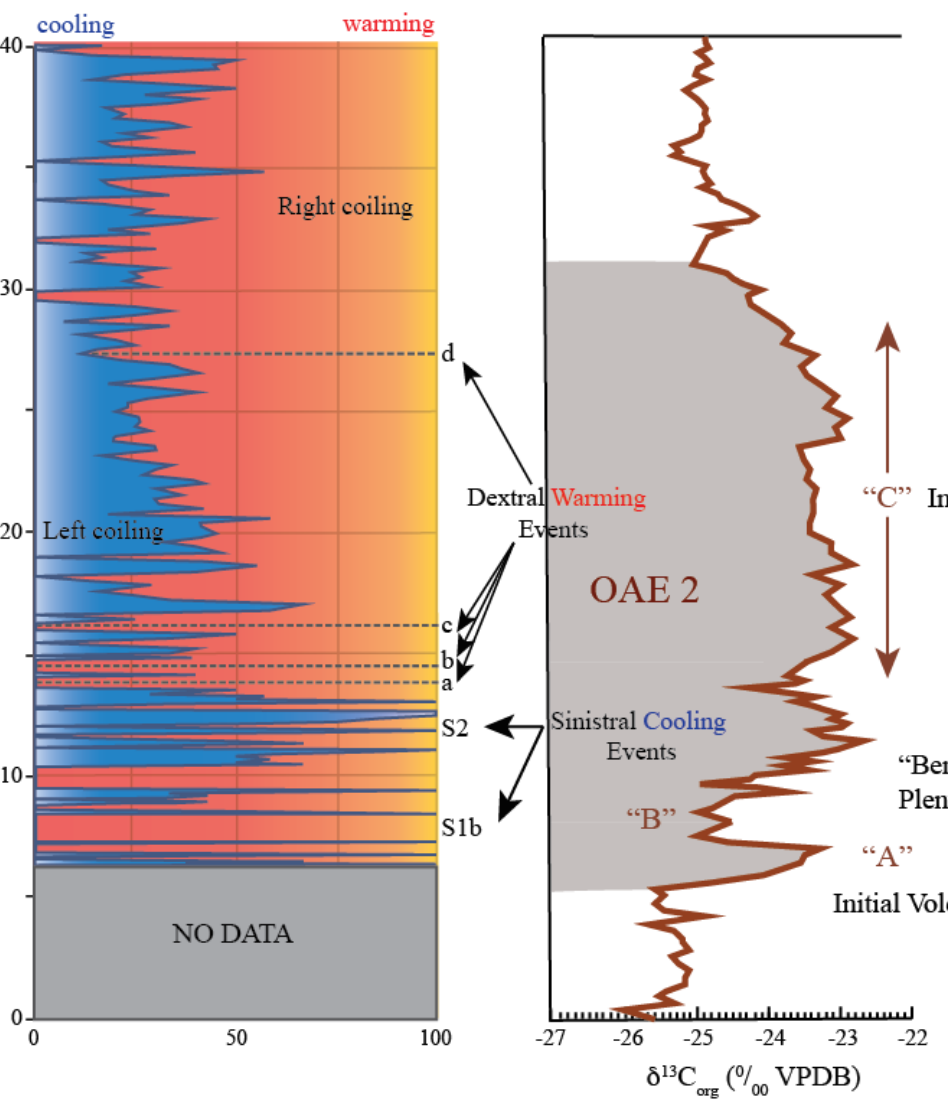

Increased Burial of OM

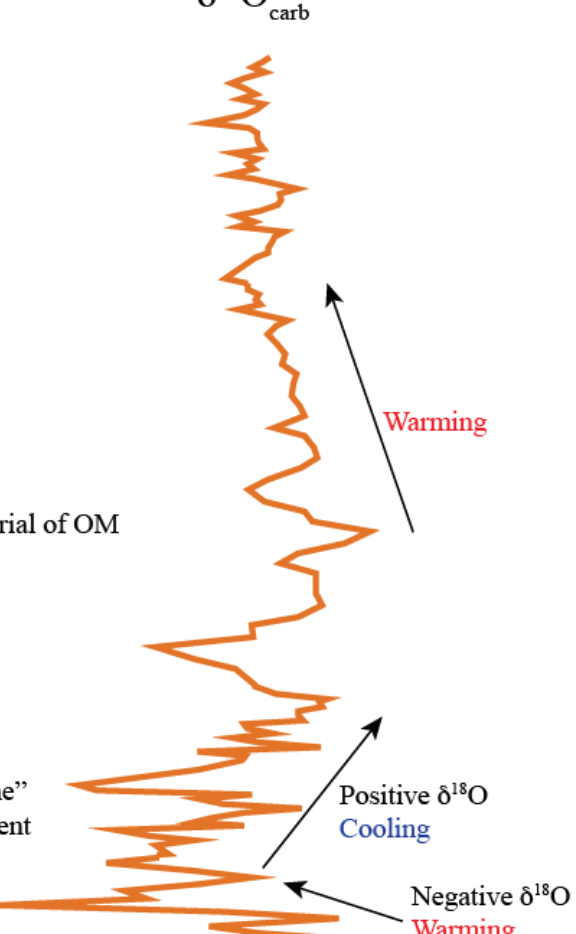

nthonic Zone" lenus Cool Event
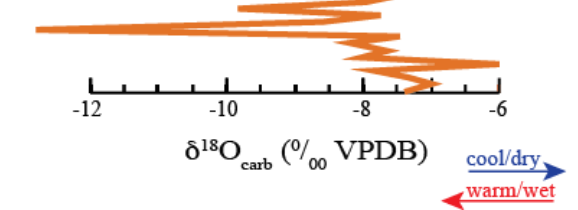

Figure 6: Summary figure showing high frequency coiling reversals of \%Sinistral Trochospiral spp. and $\delta{ }^{13} \mathrm{C}_{\text {org }}$ and $\delta{ }^{18} \mathrm{O}_{\text {carb }}$ from the core. Note the general structure of the $\delta{ }^{13} C_{\text {org }}$ excursion including the initial enrichment (" $A$ "), a brief recovery (" $B$ "), and a sustained plateau ("C"), first described by Pratt and Threlkeld, (1984). Carbon isotope "ramp up" prior to the event is coincident with the Benthonic Zone. Note the general structure of the $\delta{ }^{18} \mathrm{O}_{\text {carb }}$ in relation to cooling episodes of sinistral forms. 

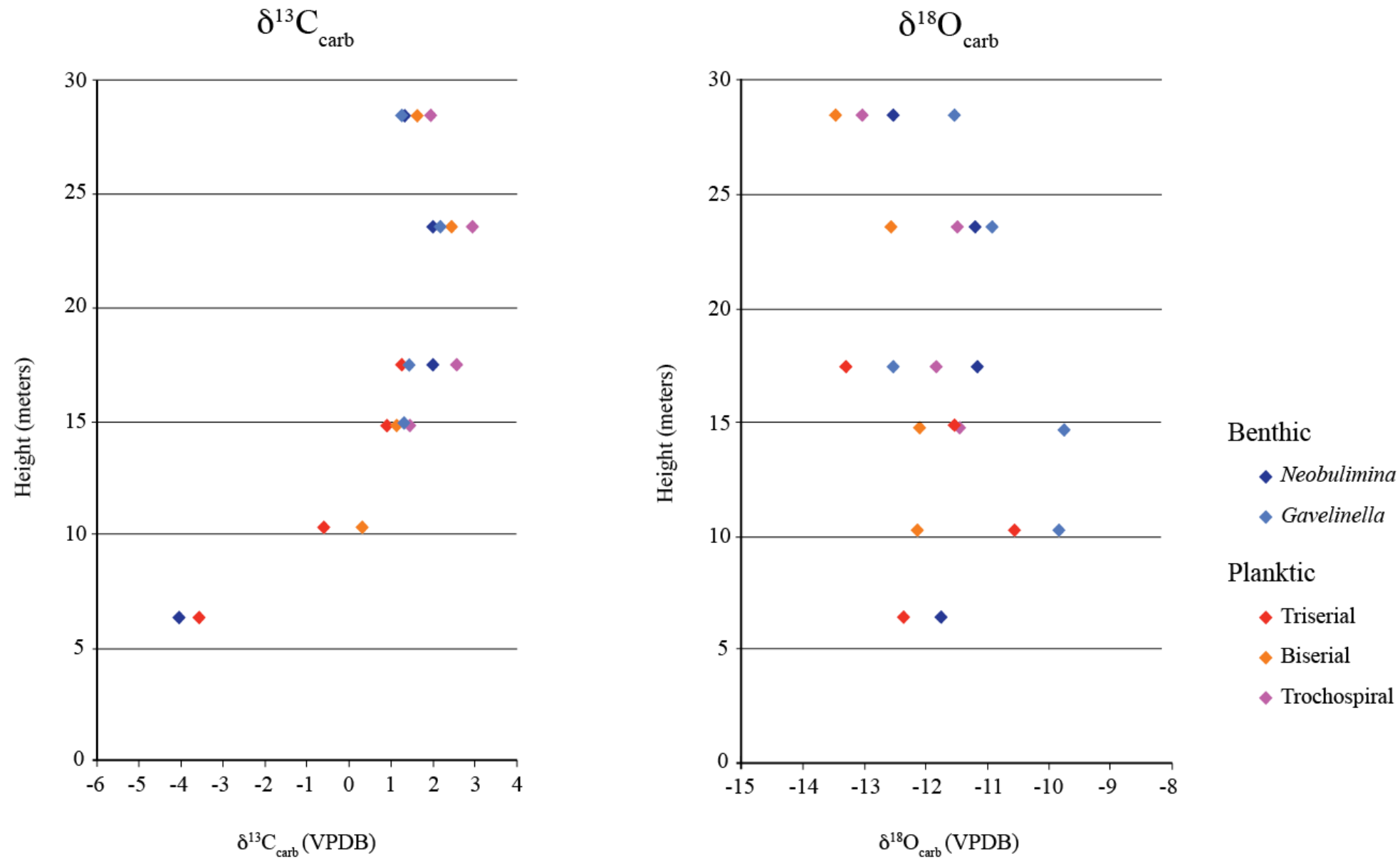

Figure 7: A comparative stable isotope $\left(\delta^{18} \mathrm{O}\right.$ and $\left.\delta^{13} \mathrm{C}\right)$ study of well-preserved specimens of planktic and benthic foraminifera. Planktic foraminifera include (biserial; Heterohelix globulosa, triserial; Guembelitria cenomana, trochospiral; Hedbergella delrioensis) and benthic foraminifera include (Gavelinella dakotensis, Neobulimina albertensis) enabled us to determine the preferred depth habitat and mode of life for each specimen. Depth-stratified foraminiferal assemblages from marine sites exhibit a trend of increasing $\delta^{18} \mathrm{O}$ and decreasing $\delta{ }^{13} \mathrm{C}$ with depth (Fairbanks et al., 1982). 


\section{Sedimentation Rates (cm/kyr) across the Western Interior Seaway}

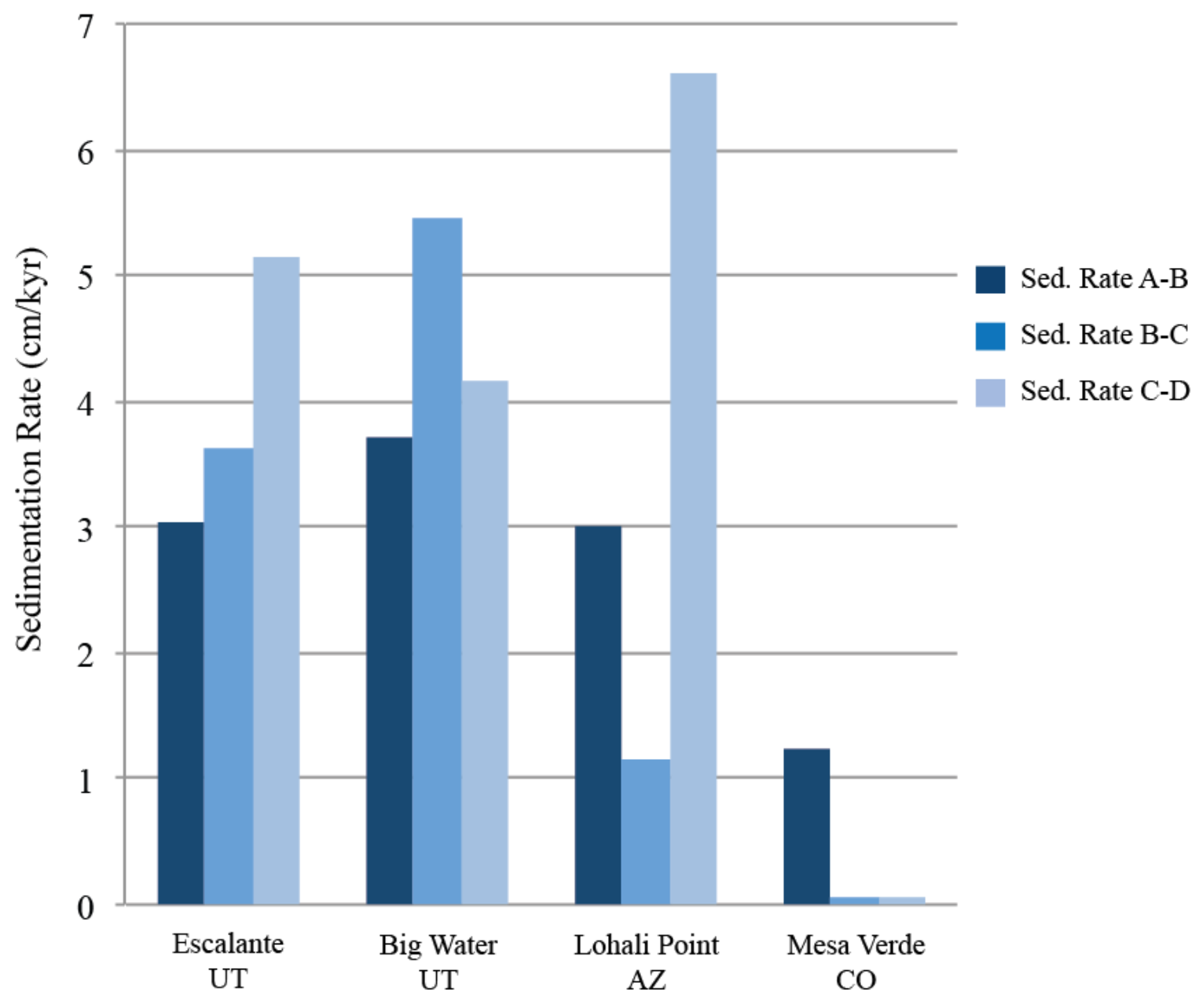

Figure 8: Sedimentation rates through the Cenomanian-Turonian boundary interval. Sites include Escalante (UT), Big Water (UT), Lohali Point (AZ), and Mesa Verde (CO).

Sedimentation rates are determined based on bentonite ages from Meyers et al. (2012). The more proximal Escalante and Big Water generally have higher rates. Mesa Verde was situated on the forebulge during the time of the Cenomanian-Turonian boundary and experienced greatly reduced rates of sediment accumulation. Note the abrupt increase in sedimentation rate C-D at Lohali Point. 


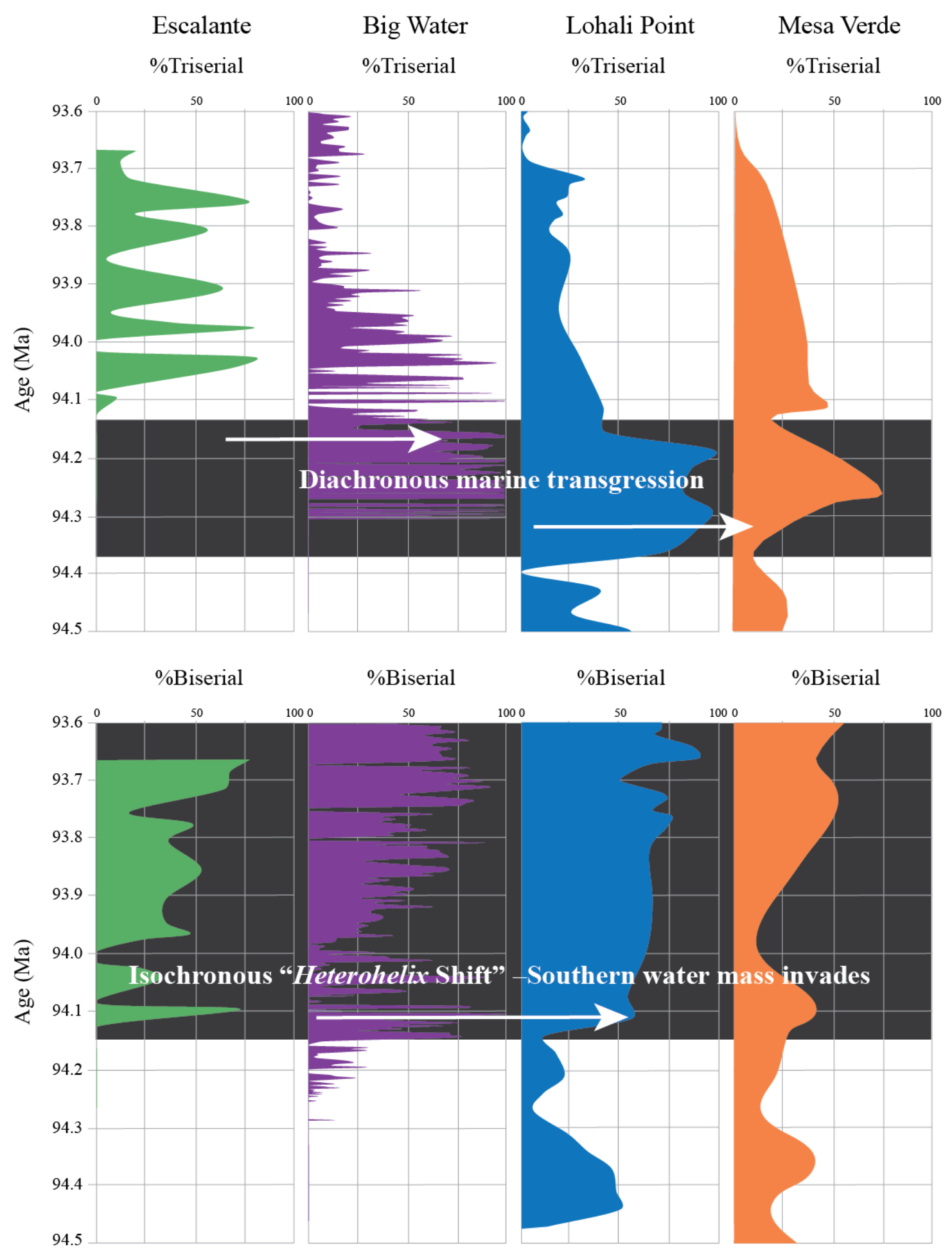

Figure 9a: Proportion of planktic morphotypes to total planktic foraminifera through the Cenomanian-Turonian boundary interval. Sites include Escalante (UT), Big Water (UT), Lohali Point (AZ), and Mesa Verde (CO). Published datasets from Leckie et al. (1998). 


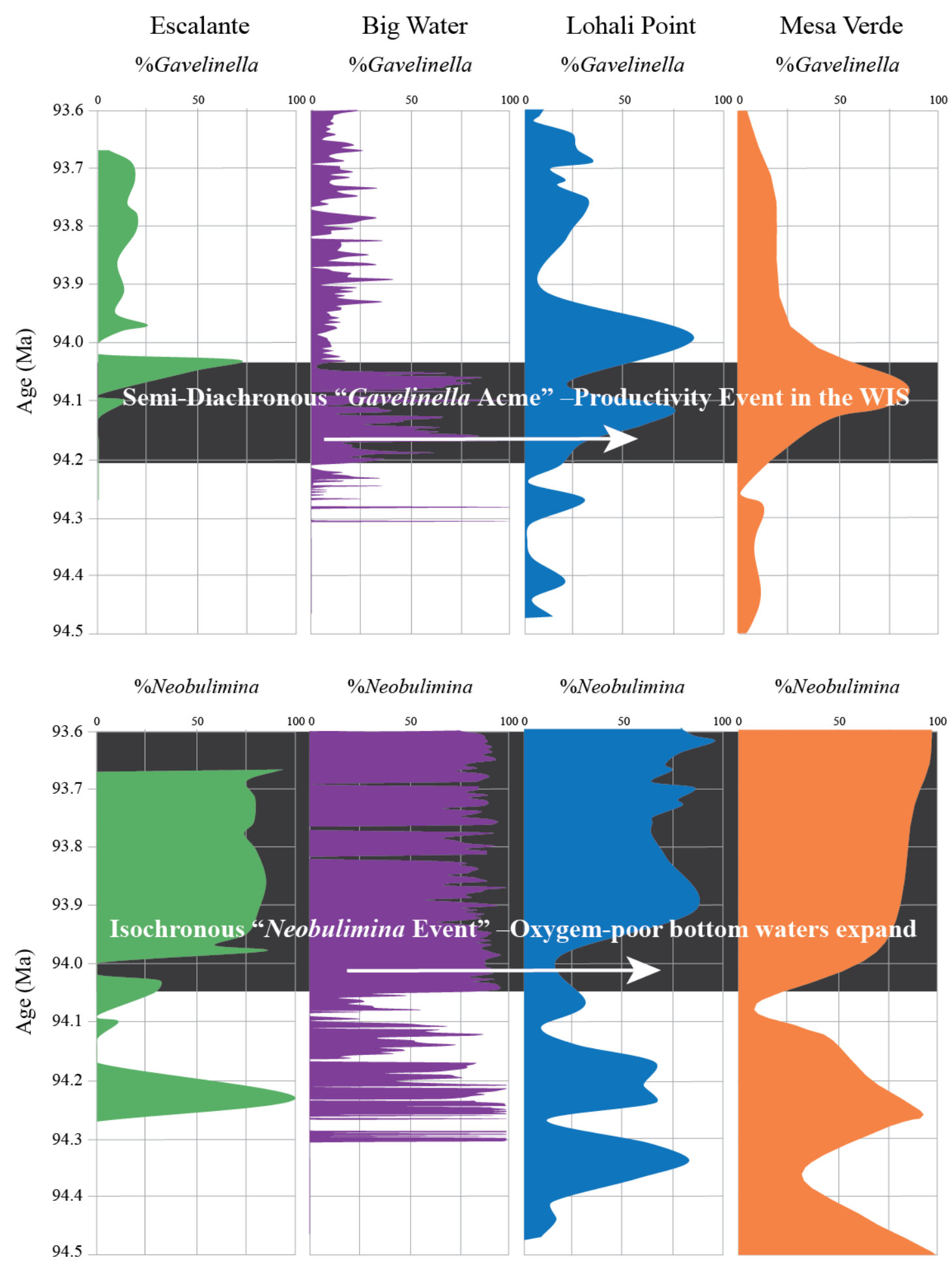

Figure 9b: Proportion of benthic species to total benthic foraminifera through the Cenomanian-Turonian boundary interval. Sites include Escalante (UT), Big Water (UT), Lohali Point (AZ), and Mesa Verde (CO). Published datasets from Leckie et al. (1998). 

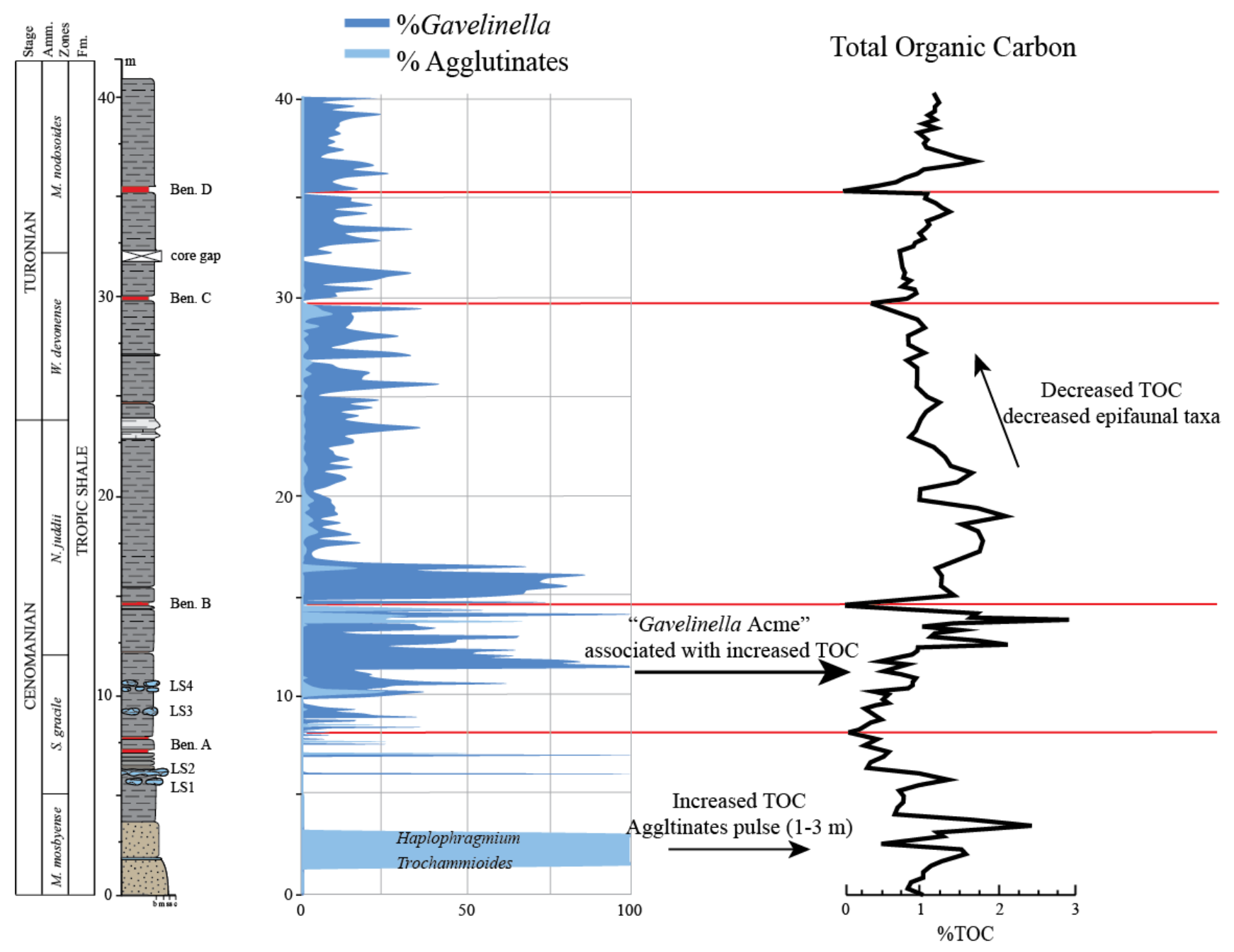

Figure 10: Comparison of \%TOC and benthic foraminifer abundances during OAE 2. Initial increase in TOC values corresponds to increasing abundance of \%Gavelinella dakotensis until $17.0 \mathrm{~m}$, where Gavelinella abruptly drops off and infaunal Neobulimina albertensis dominates the assemblages. 


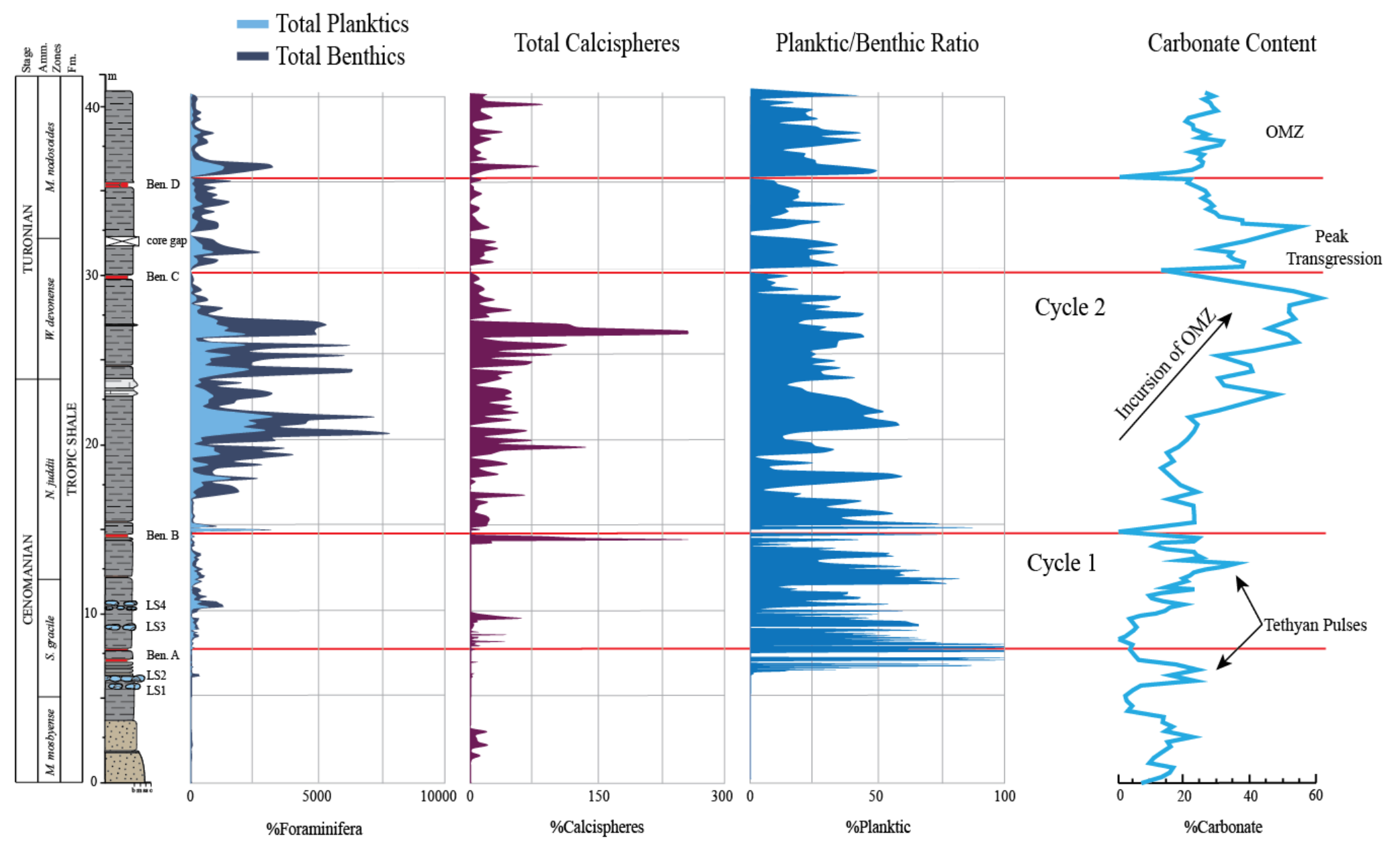

Figure 11: Comparison of bulk carbonate (blue line) and foraminifera (planktic and benthic total abundances) during the OAE 2 event from Big Water, Utah. Bulk carbonate reflects the transgression of the sea with the deepening upwards section recording the influx of normal marine taxa into the basin. Note the annotations for transgression-regression Cycles 1-2. 
APPENDIX C

PLATES 


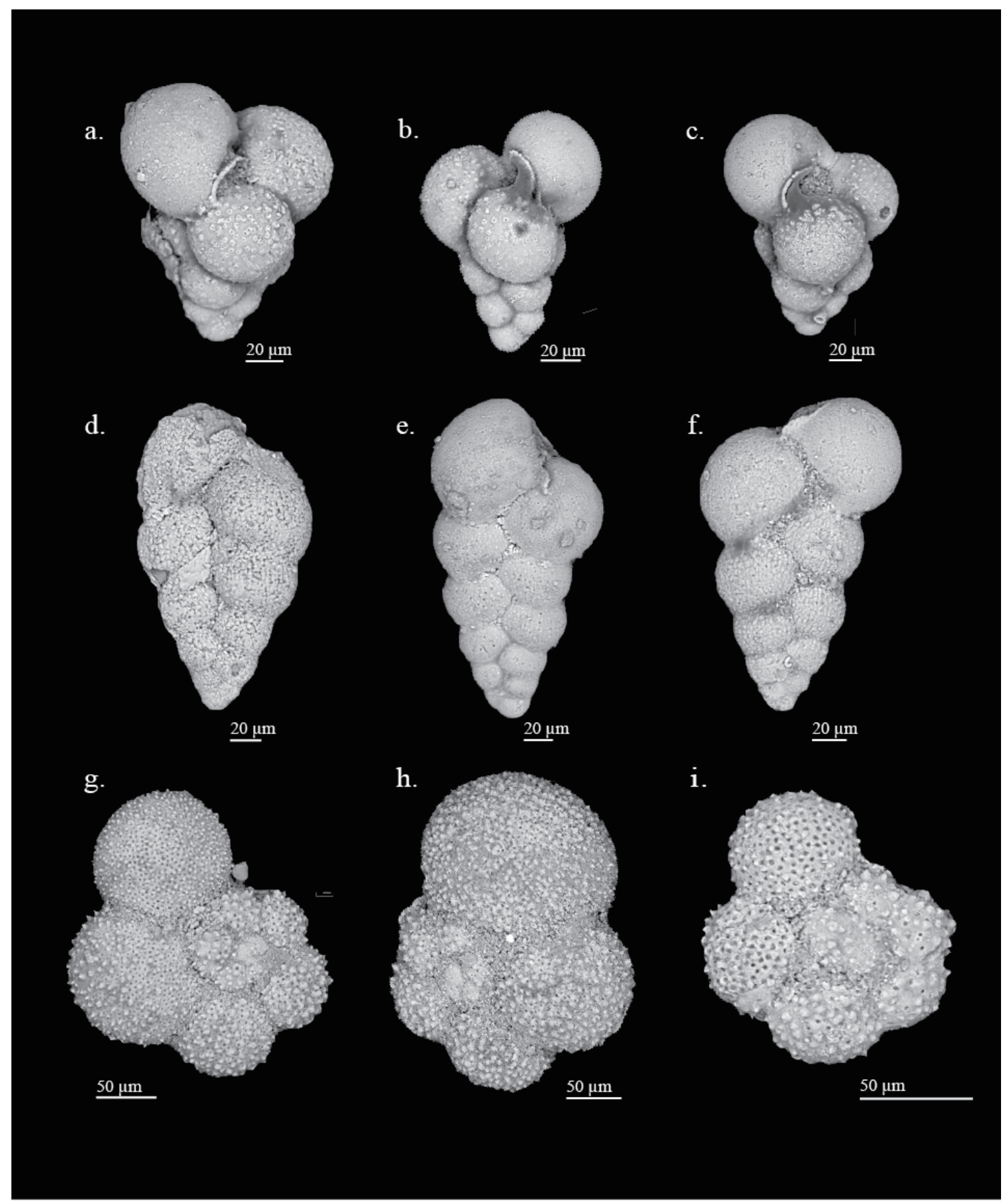

Plate 1: Planktic foraminifera from the Tropic Shale. a-c. Guembelitria cenomana $14.48 \mathrm{~m}$; d-e. Heterohelix globulosa 13.4 m; f. H. globulosa 14.8 m; g. Hedbergella delrioensis 23.4 $\mathrm{m}$; h-i. H. delrioensis 25.6 


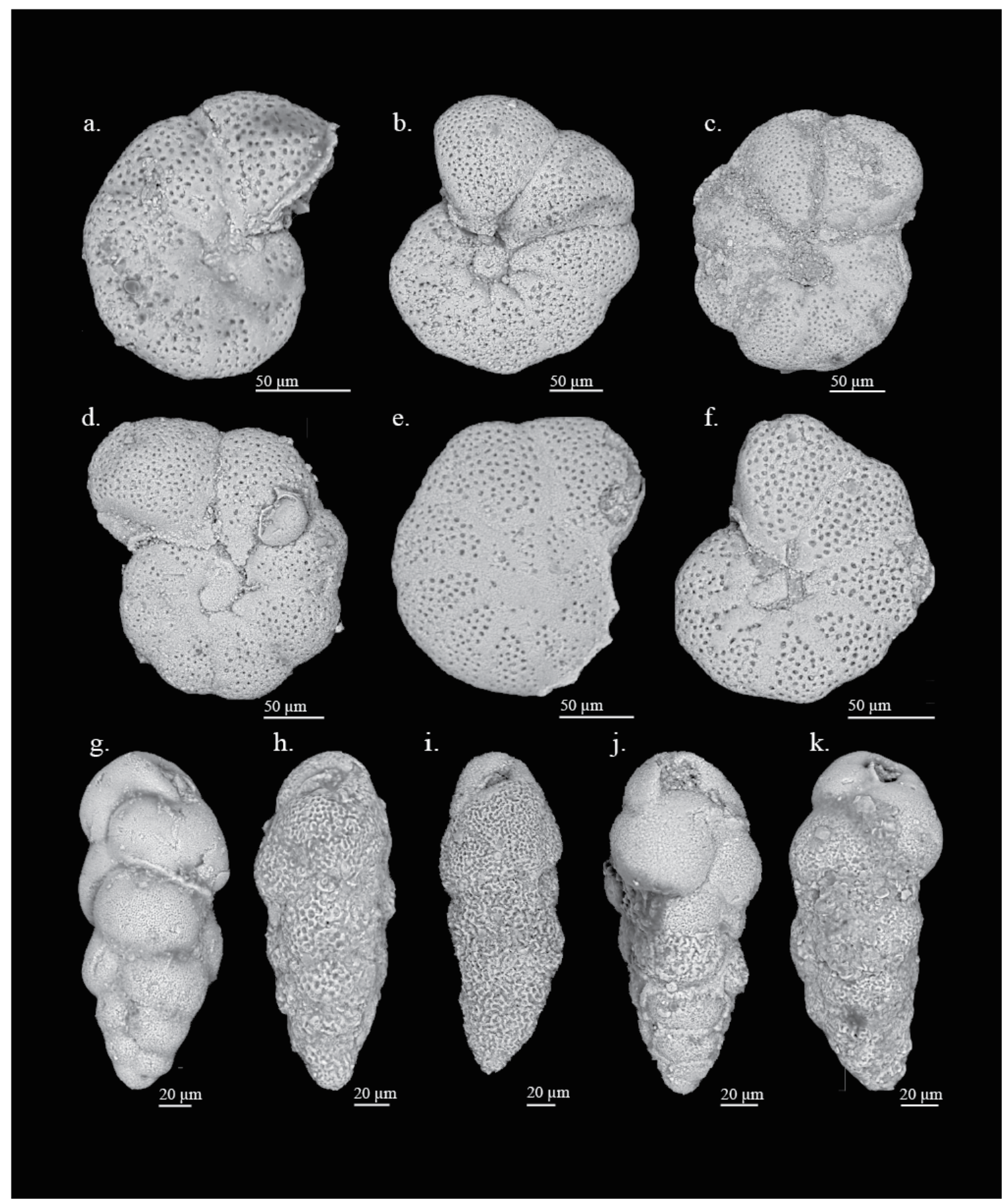

Plate 2: Benthic foraminifera from the Tropic Shale. a. Gavelinella dakotensis $10.4 \mathrm{~m}$; b-d. G. dakotensis $14.8 \mathrm{~m}$; e. G. dakotensis $23.4 \mathrm{~m}$; f. G. dakotensis $25.6 \mathrm{~m}$; g. Neobulimina albertensis $6.35 \mathrm{~m}$; h. N. albertensis $18.6 \mathrm{~m}$; i. N. albertensis $23.4 \mathrm{~m}$; j. N. albertensis 25.6 $\mathrm{m}$; k. N. albertensis $28.2 \mathrm{~m}$. 


\section{BIBLIOGRAPHY}

Albright L.B., Gillette D.D., Titus A.L., 2007, Plesiosaurs from the Upper Cretaceous (CenomanianTuronian) Tropic Shale of southern Utah, Vertebrate Paleontology, v. 27, p. 31-58.

Ashckenazi-Polivoda S., Edelman-Furstenberg Y., Almogi-Labin A., Benjamini C., 2010, Characterization of lowest oxygen environments within ancient upwelling environments: Benthic foraminifera assemblages, Palaeogeography, Palaeoclimatology, Palaeoecology, v. 289, p. 134-144.

Arthur M.A., Schlanger S.O., Jenkyns H.C., 1987, The Cenomanian-Turonian oceanic anoxic event, II. Paleoceanographic controls on organic matter production and preservation, in Brooks J., Fleet A. (Eds.), Marine Petroleum Source Rocks, Geological Society Special Publication 26, p. $410-420$.

Arthur M.A., Sageman B.B, 2005, Sea level control on source rock development: perspectives from the Holocene Black Sea, the mid-Cretaceous Western Interior Basin of North America, and the Late Devonian Appalachian Basin, in Harris N.B., (Ed.), The Deposition of Organic Carbon-rich Sediments: Models, Mechanisms and Consequences, Society for Sedimentary Geology Special Publication, 82, Tulsa, p. 35-59.

Barclay R.S., McElwain J.C., Sageman B.B., 2010, Carbon sequestration activated volcanic $\mathrm{CO}_{2}$ pulse during Ocean Anoxic Event 2, Nature Geosciences, v. 3, p. 205-208.

Barlow L.K., Kauffman E.G., 1985, Depositional cycles in the Niobrara Formation, Colorado Front Range, in Pratt L.M., Kauffman E.G., Zelt F.B., (Eds.), Fine-grained Deposits and Biofacies of the Cretaceous Western Interior Seaway: Evidence of Cyclic Sedimentary Processes, Society of Economic Paleontologists and Mineralogists, Field Trip Guidebook No. 4, p. 199208.

Bauch D., Darling K., Simstich J., Bauch H.A., Erienkeuser H., Kroon D., 2003, Palaeoceanographic implications of genetic variations in living North Atlantic Neogloboquardine pachyderma, Nature, v. 424, p. 299-302.

Bernhard J.M., 1986, Characteristic assemblages and morphologies of benthic foraminifera from anoxic, organic-rich deposits: Jurassic through Holocene, Journal of Foraminiferal Research, v. 16, p. 207-215.

Boersma A., Premoli Silvia I., 1989, Atlantic Paleogene biserial heterohelicid foraminifera and oxygen minima, Paleoceanography, v. 4, p. 271-286.

Bond G.C., Broecker W., Johnsen S., Mcmanus J., 1993, Correlations between climate records from North Atlantic sediments and Greenland ice, Nature, v. 365, p. 143-147.

Bralower T.J., Fullagar P.D., Paull C.K., Dwyer G.S., Leckie R.M., 1997, Mid-Cretaceous strontiumisotope stratigraphy of deep-sea sections, Geological Society of America Bulletin, v. 109, p. 1421-1442.

Caron M., Dall'Angolo S., Accarie H., Barrare E., Kauffman E.G., Amedro F., Robaszynski F., 2006, High-resolution stratigraphy of the Cenomanian-Turonian boundary interval at Pueblo (USA) and Wadi Bahloul (Tunisia): Stable isotope and bio-events correlation, Geobios, v. 39, p. 171-200. 
Corfield R.M., Hall M.A., Brasier M.D., 1990, Stable isotope evidence for foraminiferal habitats during the development of the Cenomanian/Turonian ocean anoxic event, Geology, v. 18, p. 175-178.

Darling K., Kucera M., Kroon D., Wade C.M., 2006, A resolution for the coiling direction paradox in Neogloboquadrina pachyderma, Paleoceanography, v. 21, PA2011.

Desmares D., Crognier N., Bardin J., Teste M., Beaudoin B., Grosheny D., 2015, A new proxy for Cretaceous paleoceanographic and paleoclimatic reconstructions: coiling direction changes in the planktonic foraminifera Muricohedbergella delrioensis, Palaeogeography Palaeoclimatology Palaeoecology, in review.

Eicher D.L., 1969, Paleobathymetry of Cretaceous Greenhorn sea in eastern Colorado, American Association of Petroleum Geologists Bulletin, v. 53, p. 1075-1090.

Eicher D.L., Worstell P., 1970, Cenomanian and Turonian foraminifera from the Great Plains, United States: Micropaleontology, v. 16, p. 269-324.

Eicher D.L., Diner R., 1985, Foraminifera as indicators of water mass in the Cretaceous Greenhorn Sea, western interior, in Pratt L.M., Kauffman E.G., Zelt F.B., (Eds.), Fine-grained Deposits and Biofacies of the Cretaceous Western Interior Seaway: Evidence of Cyclic Sedimentary Processes, Society of Economic Paleontologists and Mineralogists, Field Trip Guidebook No. 4, p. 60-71.

Elder W.P., 1987, Cenomanian-Turonian stage boundary extinctions in the Western Interior of the United States, Ph.D. Thesis, University of Colorado, p. 621.

Elder W.P., 1988, Geometry of Upper Cretaceous bentonite beds: Implications about volcanic source areas and paleowind patterns, Western Interior, United States: Geology, v. 16, p. 835-838.

Elder W.P., 1989, Molluscan extinction patterns across the Cenomanian-Turonian stage boundary in the Western Interior of the United States, Paleobiology, v. 15, p. 299-320.

Elder W.P., 1991, Molluscan paleoecology and sedimentation patterns of the Cenomanian Turonian extinction interval in the southern Colorado Plateau region, in Nations J.D., Eaton J.G., (Eds.), Stratigraphy, Depositional Environments, and Sedimentary Tectonics of the Western Margin, Cretaceous Western Interior Seaway: Boulder, Geological Society of America Special Paper 260, p. 113-137.

Elder W.P., Gustason E.R., Sageman B.B., 1994, Correlation of basinal carbonate cycles to nearshore parasequences in the Late Cretaceous Greenhorn seaway, Western Interior U.S.A. Geologic Society of America Bulletin, v. 106, p. 892-902.

Elderbak K., Leckie R.M., Tibert N.E., 2014, Paleoenvironmental and paleoceanographic changes across the Cenomanian-Turonian Boundary Event (Ocean Anoxic Event 2) as indicated by foraminiferal assemblages from the eastern margin of the Cretaceous Western Interior Seaway, Palaeogeography, Palaeoclimatology, Palaeoecology, v. 413, p. 29-48.

Elderbak K., Leckie R.M., 2016, Paleocirculation and foraminiferal assemblages of the Cenomanian-Turonian Bridge Creek Limestone bedding couplets: Productivity vs. dilution during OAE 2, Cretaceous Research, in press. 
Erbacher J., Hemleben C., Huber B.T., Markey M., 1999, Correlating environmental changes during Albian Oceanic Anoxic Event 1B using benthic foraminiferal palaeoecolgy, Marine Micropalaontology, v. 38, p. 7-28.

Ericson D.B., 1959, Coiling direction of Globigerina pachyderma as a climatic index, Science, v. 130 , p. $219-220$.

Fairbanks R.G., Sverdlove M., Free R., Wiebe P.H., Be A.W.H., 1982, Vertical distribution and isotopic fractionation of living planktonic foraminifera from the Panama Basin, Nature, v. 298, p. 841-844.

Friedrich O., Erbacher J., Mutterlose J., 2006, Paleoenvironmental change across the Cenomanian/Turonian boundary event (Oceanic Anoxic Event 2) as indicated by benthic foraminifera from the Demerara Rise (ODP Leg 207), Rev. Micropaleontol, v. 49, p.121-139.

Friedrich O., Herrle J.O., Wilson P.A., Cooper M.J., Erbacher J., Hemleben C., 2009, Early Maastrichtian carbon cycle perturbation and cooling event: Implications from the South Atlantic Ocean, Paleoceanography, v. 24, p. PA2211. doi:10.1029/2008PA001654.

Friedrich O., 2010, Benthic foraminifera and their role to decipher paleoenvironment during midCretaceous Oceanic Anoxic Event -the "anoxic benthic foraminifera" paradox, Revue de Micropaleontologie, v. 53, p. 175-192.

Gale A.S., Christensen W.K., 1996, Occurrence of the belemnite Actinocamax plenus in the Cenomanian of SE France and its significance, B. Geol. Society, Denmark, v. 43, p. 68-77.

Gale A.S., Voigt S., Sageman B.B., Kennedy W.J., 2008, Eustatic sea-level record for the Cenomanian (Late Cretaceous) -Extension to the Western Interior Basin, USA, Geology, v. 36, p. $859-862$.

Gebhardt H., Kuhnt W., Holbourn A., 2004, Foraminferal response to sea level change, organic flux and oxygen deficiency in the Cenomanian of the Tarfaya Basin southern Morocco, Marine Micropaleontology, v. 53, p. 133-157.

Gooday A.J., 1993, Deep-sea benthic foraminifera species which exploit phytodetritus: Characteristic features and controls on distribution, Marine Microplaeontology, v. 22, p. 187205.

Hart M.B., 1999, The evolution and biodiversity of Cretaceous Planktonic Foraminiferida, Geobios, v. 32, p. 247-255.

Hattin D.E., 1971, Widespread, synchronously deposited, burrow-mottled limestone beds in Greenhorn Limestone (Upper Cretaceous) of Kansas and central Colorado, American Association of Petroleum Geologists Bulletin, v. 55, p. 421-431.

Hattin D.E., 1985, Distribution and significance of widespread, time-parallel pelagic limestone beds in the Greenhorn Limestone (Upper Cretaceous) of the central Great Plains and southern Rocky Mountains, in Pratt L.M., Kauffman E.G., Zelt F.B., (Eds.), Fine-grained Deposits and Biofacies of the Cretaceous Western Interior Seaway: Evidence of Cyclic Sedimentary Processes, Society of Economic Paleontologists and Mineralogists, Field Trip Guidebook No. 4, p. 28-37. 
Hattin D.E., 1986, Interregional model for deposition of Upper Cretaceous pelagic rhythmites, U.S. western interior, Paleogeography, v. 1, p. 483-494.

Hay W.W., Eicher D.L., Diner R., 1993, Physical oceanography and water masses of the Cretaceous Western Interior Seaway, in Caldwell W.G.E., Kauffman E.G., (Eds.), Evolution of the Western Interior Basin, Geological Association of Canada Special Paper 39, p. 219241.

Holbourn A.E.L., Kuhnt W., 1998, Turonian-Santonian benthic foraminiferal assemblages from Site 959D (Cote d'Ivoire-Ghana Transform Margin, Equatorial Atlantic): Indication of a Late Cretaceous oxygen minimum zone, in Mascle J., Lohmann G.P., Moullade M., (Eds.), Proceedings of the Ocean Drilling Program, Scientific Results 159, Ocean Drilling Program, College Station, TX, p. 375-387.

Huber B.T., Hodell D.A., Hamilton C.P., 1995, Middle-Late Cretaceous climate of the southern high latitudes: Stable isotopic evidence for minimal equator-to-pole thermal gradients, Geological Society of America Bulletin, v. 107, p. 1164-1191.

Huber B.T., Norris R.D., MacLeod K.G., 2002, Deep-sea paleotemperature record of extreme warmth during the Cretaceous, Geology, v. 30, p. 123-126.

Jarvis I., Mabrouk A., Moody R.T.J., de Cabrera S.C., 2002, Late Cretaceous (Campanian) carbon isotope events, sea-level change and correltation of the Tethyan and Boreal realms, Palaeogeography, Palaeoclimatology, Palaeoecology, v. 188, p. 215-248.

Jarvis I., Lignum J.S., Grocke D.R., Jenkyns H.C., Pearce M.A., 2011, Black Shale deposition, atmospheric $\mathrm{CO} 2$ drawdown, and cooling during the Cenomanian-Turonian Oceanic Anoxic Event, Paleoceanography, v. 26.

Jefferies R.P.S., 1962, The paleoecology of the Actinocamax plenus Subzone (Lowest Turonian) in the Anglo-Paris basin, Paleontology, v. 4, p. 609-647.

Jefferies R.P.S., 1963, The stratigraphy of the Actinocamax plenus Subzone (Lowest Turonian) in the Anglo-Paris Basin, Proceeding of Geologists' Association, London, v. 74, p. 1-33.

Jenkyns H.C., Matthews A., Tsiko H., Erel Y., 2007, Nitrate reduction, sulfate reduction, and sedimentary iron isotope evolution during the Cenomanian-Turonian oceanic anoxic event, Paleoceanography, v. 22, p. PA3208.

Jenkyns H.C., 2010, Geochemistry of oceanic anoxic events, Geochemistry Geophysics Geosystems, v. 11, Q03004.

Jorissen F.J., De Stigter H.C., Widmark J.G.V., 1995, A conceptual model explaining benthic foraminiferal microhanitats, Marine Micropaleontology, v. 22, p. 3-15.

Jorissen F.J., 1999, Benthic foraminiferal microhabitats below the sediment-water interface, in Sen Gupta B.K., (Ed.) Modern Foraminifera, Kluwer, p. 161-179.

Kaiho K., 1994, Benthic foraminiferal dissolved-oxygen index and dissolved-oxygen levels in the modern ocean, Geology, v. 22, p. 719-722.

Kaiho K., 1999, Effect of organic carbon flux and dissolved oxygen on the benthic foraminiferal oxygen index (BFOI), Marine Micropaleontology, v. 37, p. 67-76. 
Kauffman E.G., 1975, Dispersal and biostratigraphic potential of Cretaceous benthonic Bivalvia in the Western Interior, in Caldwell W.G.E., (Ed.), The Cretaceous System in the Western Interior of North America, Geological Association of Canada, Special Paper 13, p. 163-194.

Kauffman E.G., 1977, Geological and biological overview: western interior Cretaceous basin: The Mountain Geologist, v. 14, p. 75-100.

Kauffman E.G., 1984, Paleobiogeography and evolutionary response dynamic in the Cretaceous Western Interior Seaway of North America, in Westermann G.E.G (Ed.), Jurassic-Cretaceous Biochronology and Paleogeography of North America, Geological Association of Canada, Special Paper 27, p. 273-306.

Kauffman E.G., Sageman B.B., Kirkland J.I., Elder W.P., Harries P.J., Villamil T., 1993, Molluscan biostratigraphy of the Cretaceous Western Interior Basin, North America, in Caldwell W.G.E., Kauffman E.G., (Eds.), Evolution of the Western Interior Basin: Geological Association of Canada, Special Paper 39, p. 397-434.

Keller G., Pardo A., 2004, Age and paleoenvironment of the Cenomanian-Turonian global stratotype section and point at Pueblo, Colorado, Marine Micropaleontology, v. 51, p. 95-128.

Kennedy W.J., Walaszczyk I., Cobban W.A., 2005, The Global Boundary Stratotype Section and Point for the base of the Turonian Stage of the Cretaceous: Pueblo, Colorado, U.S.A. Episodes, v. 28, p. 93-104.

Kerr A.C., Tarney J., Marriner G.F., Nivia A., Saunders A., 1997, The Caribbean-Colombian Cretaceous igneous province: The internal anatomy of oceanic plateau, in Mahoney J.J., Coffin M.F., (Eds.), Large Igneous Provinces: Continental, Oceanic and Planetary Volcanism: American Geophysical Union Monograph 100, Washington D.C., p. 123-144.

Kerr A.C., 1998, Oceanic plateau formation: a cause of mass extinction and black shale deposition around the Cenomanian-Turonian boundary? Journal of the Geological Society, v. 155, p. 619-626.

Kirkland J.I., 1991, Lithostratigraphic and biostratigraphic framework for the Mancos Shale (late Cenomanian to middle Turonian) at Black Mesa, northeastern Arizona, in Nations J.D., Eaton J.G., (Eds.), Stratigraphy, Depositional Environments, Sedimentary Tectonics of the Western Margin, Cretaceous Western Interior Seaway, Geological Society of America, Special Paper 260 , p. 85-111.

Kirkland J.I., Leckie R.M., Elder W.P., 1995, A new principal reference section for the Mancos Shale (Late Cretaceous) at Mesa Verde National Park, in Santucci V.L., McClelland L., (Eds.), National Park Service Paleontological Research: Washington, D.C., National Park Service Technical Report, NPS/NRPO/NRTR-95/16 p. 77-81.

Koster E.C., 1993, Facies relationships and systems tract in the late Holocene Mississippi Delta Plain: Journal of Sedimentary Petrology, v. 63, p. 727-733.

Koutsoukos E.A.M., Leary P.N., Hart M.B., 1990, Latest Cenomanian-earliest Turonian low-oxygen tolerant benthonic foraminifera: a case-study from the Sergipe basin (NE Brazil) and the western Anglo-Paris basin (southern England), Paleogeography, Paleoclimatology, Paleoecology, v. 77, p. 145-177.

Kroopnick P.M., 1985, The distribution of ${ }^{13} \mathrm{C}$ of $\mathrm{CO}_{2}$ in the world oceans with Deep Sea Research, v. 32, p. 57-84. 
Kuhnt W., Luderer F., Neferbragt S., Thurow J., Wagner T., 2005, Orbital-scale record of the late Cenomanian-Turonian oceanic anoxic event (OEA-2) in the Tarfaya Basin (Morocco), International Journal of Earth Sciences, v. 94, p. 147-159.

Kuypers M.M.M., Pancost R.D., Nijenhuis I.A., Damste J.S.S., 2002, Enhanced productivity led to increased organic carbon burial in the euxinic North Atlantic basin during the late Cenomanian oceanic anoxic event, Paleoceanography, v. 17, PA1051.

Laurin J., Sageman B.B., 2007, Cenomanian-Turonian coastal record in SW Utah, U.S.A.: Orbitalscale transgressive-regressive events during Oceanic Anoxic Event II, Journal of Sedimentary Research, v. 77, p. 731-756.

Laurin J., Meyers S.R., Ulicny D., Jarvis I., Sageman B.B., 2015, Axial obliquity control on the greenhouse carbon budget through middle- to high-latitude reservoirs, Paleoceanography, doi:10.1002/2014PA002736.

Leckie R.M., 1985, Foraminifera of the Cenomanian-Turonian boundary interval, Greenhorn Formation, Rock Canyon Anticline, Pueblo, Colorado, in Pratt L.M., Kauffman E.G., Zelt F.B., (Eds.), Fine-grained Deposits and Biofacies of the Cretaceous Western Interior Seaway: Evidence of Cyclic Sedimentary Processes: Society of Economic Paleontologist and Mineralogists, Field Trip Guidebook No. 4, p. 139-149.

Leckie R.M., 1987, Paleoecology of mid-Cretaceous planktic foraminifera: A comparison of open ocean and epicontinental sea assemblages, Micropaleontology, v. 33(2), p. 164-176.

Leckie R.M., 1989, A paleoceanographic model for the early evolutionary history of planktonic foraminifera, Palaeogeography, Palaeoclimatology, Palaeoecology, v. 73, p. 107-138.

Leckie R.M., Schmidt M.G., Finkelstein D., Yuretich R., 1991, Paleoceanographic and paleoclimatic interpretations of the Mancos Shale (Upper Cretaceous), Black Mesa Basin, Arizona, in Nations, J.D., Eaton, J.G., (Eds.), Stratigraphy, Depositional Environments, and Sedimentary Tectonics of the Western Margin, Cretaceous Western Interior Seaway: Geologic Society of America, Special Paper 260, p. 139-152.

Leckie R.M., Kirkland J.I., Elder W.P., 1997, Stratigraphic framework and correlation of a principal reference section of the Mancos Shale (Upper Cretaceous), Mesa Verde, Colorado, in Anderson O.J., Kues B.S., Lucas S.G., (Eds.), Mesozoic Geology and Paleontology of the Four Corners Region: New Mexico Geological Society, $48^{\text {th }}$ Annual Field Conference, Cortez, NM, p. 163-216.

Leckie R.M., Yuretich R.F., West O.L.O., Finkelstein D., Schmidt M., 1998, Paleoceanography of the southwestern Western Interior Sea during the time of the Cenomanian-Turonian boundary (Late Cretaceous), in Dean, W.E., Arthur, M.A., (Eds.), Stratigraphy and Paleoenvironments of the Cretaceous Western Interior Seaway, USA, SEPM Concepts in Sedimentology and Paleontology 6, p. 101-126.

Leckie R.M., Bralower T.J., Cashman R., 2002, Oceanic anoxic events and plankton evolution: Biotic response to tectonic forcing during the mid-Cretaceous, Paleoceanography, v. 17.

Leckie R.M., Olson H.C., 2003, Foraminifera as proxies for sea-level change on siliclastic margins, in Olson H.C., Leckie R.M., (Eds.), Micropaleontologic Proxies for Sea-level Change and Stratigraphic Discontinuities, SEPM Special Publication 75, p. 5-19. 
Leithold E.L., 1993, Preservation of laminated shale in ancient clinoforms: Comparison to modern subaqueous deltas, Geology, v. 21, p. 359-362.

Leithold E.L., 1994, Stratigraphical architecture at the muddy margin of the Cretaceous Western Interior Seaway, southern Utah, Sedimentology, v. 41, p. 521-542.

Leithold E.L., Dean W.E., 1998, Depositional processes and carbon burial on a Turonian prodelta at the margin of the Western Interior Seaway, in Dean W.E., Arthur M.A., (Eds.), Stratigraphy and Paleoenvironments of the Western Interior Seaway, U.S.A., Tulsa Society for Sedimentary Geology, Concepts in Sedimentology and Paleontology 6, p. 189-200.

Lowery C.M., Corbett M.J., Leckie R.M., Watkins D., Miceli Romero A., Pramudito A., 2014, Foraminiferal and nannofossil paleoecology and paleoceanography of the CenomanianTuronian Eagle Ford Shale of southern Texas, Palaeogeography, Palaeoclimatology, Palaeoecology, v. 413, p. 49-65.

McCabe D.H., Parrish J.T., 1992, Tectonic and climatic controls on the distribution and quality of Cretaceous coals, in McCabe P.J., Parrish J.T., (Eds.), Controls on the Distribution and Quality of Cretaceous Coals: Geological Society of America, Special Paper 267, p. 1-16.

Meyers S.R., Sageman B.B., 2004, Detection, quantification, and significance of hiatuses in pelagic and hemipelagic strata, Earth and Planetary Science Letters, v. 224, p. 55-72.

Meyers S.R., Sageman B.B., Lyons T.W., 2005, Organic carbon burial rate and the molybdenum proxy: Theoretical framework and application to Cenomanian-Turonian Oceanic Anoxic Event 2, Paleoceanography, v. 20, PA2002, doi:10.1029/2004PA001068.

Meyers S.R., Siewert S.E., Singer B.S., Sageman B.B., Condon D.J., Obradovich J.D., Jicha B.R., Sawyer D.A., 2012a, Intercalibration of radioisotopic and astrochronologic time scales for the Cenomanian/Turonian Boundary interval, Western Interior Basin, U.S.A., Geology, v. 40, p.710.

Meyers S.R., Sageman B.B., Arthur M.A., 2012b, Obliquity forcing of organic matter accumulation during Oceanic Anoxic Event 2, Paleoceanography, v. 27, PA3212, doi:10.1029/2012PA002286.

Norris R.D., Wilson P.A., 1998, Low-latitude sea-surface temperature for the mid-Cretaceous and the evolution of planktic foraminifera, Geology, v. 26, p. 823-826.

Norris R.D., Nishi H., 2001, Evolutionary trends in coiling of tropical Paleogene planktic foraminifera, Paleobiology, v. 27(2), p. 327-347.

Parrish J.T., 1993, Mesozoic climates of the Colorado Plateau, in Morales M., (Ed.), Aspects of Mesozoic Geology and Paleontology of the Colorado Plateau: Museum of Northern Arizona, Bulletin 59, p. 1-11.

Pearce M., Jarvis I., Tocher B.A., 2009, The Cenomanian-Turonian boundary event, OAE 2 and paleoenvironmental change in epicontinental seas: New insights from the dinocyst and geochemical records, Palaeogeography, Palaeoclimatology, Palaeoecology, v. 280, p. 207234. 
Pearson P.N., Shacleton N.J., Hall M.A., 1993, Stable isotope paleoecology of middle Eocene planktonic foraminifera and multispecies isotope stratigraphy, DSDP Site 523, South Atlantic, Journal of Foraminiferal Research, v. 23, p. 123-140.

Peterson F., 1969, Cretaceous sedimentation and tectonism in the southeastern Kaiparowits region, Utah, U.S. Geological Survey Open File Report, 259.

Petrizzo M.R., Huber B.T., Wilson P.A., MacLeod K.G., 2008, Late Albian paleoceanography of the western subtropical North Atlantic, Paleoceanography, v. 23, doi:10.1029/2007PA001517.

Posamentier H.W., Jervey M.T., Vail P.R., 1988, Eustatic controls on clastic deposition: Conceptual framework, in Wilgus C.K., Hastings B.S., Kendall C.G.St.C., Posamentier H.W., Ross C.A., Van Wagoner J.C., (Eds.), Sea-level Change: An Integrated Approach, Society of Economic Paleontologists and Mineralogists Special Publication 42, p. 109-124.

Pratt L.M., Threlkeld C.N., 1984, Stratigraphic significance of ${ }^{13} \mathrm{C} /{ }^{12} \mathrm{C}$ ratios in mid-Cretaceous rocks of the Western Interior, U.S.A., in Scott D.F., Glass D.J., (Eds.), The Mesozoic of Middle North America, Canadian Society of Petroleum Geologists Memoir 9, p. 305-312.

Pratt L.M., 1985, Isotopic studies of organic matter and carbonate in rocks of the Greenhorn marine cycle, in Pratt L.M., Kauffman E.G., Zelt F.B., (Eds.), Fine-grained Deposits and Biofacies of the Cretaceous Western Interior Seaway: Society of Economic Paleontologists and Mineralogists Field Trip Guidebook 4, p. 38-59.

Sageman B.B., Rich J., Arthur M.A., Birchfield G.E., Dean W.E., 1997, Evidence for Milankovitch periodicities in Cenomanian-Turonian lithologic and geochemical cycles, Western Interior, USA, Journal of Sedimentary Research, v. 672, p. 286-302.

Sageman B.B., Meyers S.R., Arthur M.A., 2006, Orbital time scale and new C isotope record for Cenomanian-Turonian boundary stratotype, Geological Society of America, v. 34, p. 125128.

Schlanger S.O., Jenkyns H.C., 1976, Cretaceous oceanic anoxic events: Causes and consequences, Geologie en Mijnbouw, v. 55, p. 179-184.

Schlanger S.O., Arthur M.A., Jenkyns H.C., Scholle P.A., 1987, The Cenomanian Turonian Oceanic Anoxic Event, I. Stratigraphy and distribution of organic carbon-rich beds and the marine $\delta^{13} \mathrm{C}$ excursion, in Brooks, J., Fleet, A. (Eds.), Marine Petroleum Source Rocks, Geological Society Special Publication 26, p. 371-399.

Schmeisser McKean R.L., Gillette D.D., 2015, Taphonomy of large marine vertebrates in the Upper Cretaceous (Cenomanian-Turonian) Tropic Shale of southern Utah, Cretaceous Research, v. 56, p. 278-292.

Sen Gupta B.K., Machain-Castillo M.L., 1993, Benthic foraminifera in oxygen-poor habitats, Marine Micropaleontology, v. 20, p. 183-201.

Sinninghe Damste J.S., Koster J., 1998, Evidence for euxinic southern North Atlantic Ocean during the Cenomanian-Turonian ocean anoxic event, Earth Planetary Science Letters, v. 158, p. 165-173. 
Snow L.J., Duncan R.A., Bralower T.J., 2005, Trace element abundances in the Rock Canyon anticline, Pueblo, Colorado, marine sedimentary section and their relationship to Caribbean Plateau construction and Oceanic Anoxic Event 2, Paleoceanography, v. 20.

Tibert N.E., Leckie R.M., Eaton J.G., Kirkland J.I., Colin J-P., Leithold E.L., McCormic M.E., 2003, Recognition of relative sea-level change in Upper Cretaceous coal-bearing strata: A paleoecological approach using agglutinated foraminifera and ostracodes to detect key stratigraphic surfaces, in Olson H.C., Leckie R.M., (Eds.), Micropaleontologic Proxies for Sea-level Change and Stratigraphic Discontinuities, SEPM Special Publication 75, p. 263299.

Tibert N.E., 2013, Cenomanian-Turonian (Upper Cretaceous) foraminifera from the westernmost Colorado Plateau, southwest Utah, U.S.A., Micropaleontology, v. 59, p. 1-23.

Titus A.L., Powell J.D., Roberts E.M., Sampson S.D., Pollock S.L., Kirkland J.I., Albright L.B., 2005, Late Cretaceous stratigraphy, depositional environments, and macrovertebrate paleontology of Kaiparowits Plateau, Grand Staircase-Escalante National Monument, Utah, in Pederson J., Dehler C.M., (Eds.), Interior Western United States: Geological Society of America, Field Guide 6, doi:10.1130/2005.fld006(05).

Thomas E., Gooday A.J., 1996, Cenozoic deep-sea benthic foraminifers: Tracers for changes in oceanic productivity? Geology, v. 24, p. 355-358.

Turgeon S.C., Creaser R.A., 2008, Cretaceous oceanic anoxic event 2 triggered by a massive magmatic episode, Nature, v. 454, p. 323-326.

Van Helmond N.A.G.M., Sluijs A., Reichart G.J., Sinninghe Damste J.S., Slomp C.P., Brinkhuis H., 2014, A perturbed hydrological cycle during Ocean Anoxic Event 2, Geology, v. 42, p. 123126.

Van Wagoner J.C., Mitchum R.M., Campion K.M., Rahmanian V.D., 1990, Siliciclastic sequence stratigraphy in well logs, cores, and outcrops: Concepts for high-resolution correlation of time and facies, American Association of Petroleum Geologists, Methods in Exploration Series 7, $55 \mathrm{p}$.

Weimer R.J., 1970, Rates of deltaic sedimentation and intra-basin deformation, Upper Cretaceous of Rocky Mountain region, in Morgan J.P (Ed.), Deltaic sedimentation: Modern and Ancient, Society of Economic Paleontologist and Mineralogists, Special Publication 15, p.270-292.

Weimer R.J., 1983, Relations of unconformities, tectonics and sea level changes, Cretaceous of the Denver Basin and adjacent areas, in Reynolds M.W., Dolly E.D., (Eds.), Mesozoic Paleogeography of the West-Central United States: Society of Economic Paleontologists and Mineralogists, Rocky Mountain Section, Paleogeography Symposium 2, p. 225-252.

West O.L.O., Leckie, R.M., Schmidt, M., 1998, Foraminifera paleoecology and paleoceanography of the Greenhorn Cycle along the southwestern margin of the Western Interior Seaway, in Dean, W.E., Arthur, M.A., (Eds.), Stratigraphy and Paleoenvironments of the Cretaceous Western Interior Seaway, USA, SEPM Concepts in Sedimentology and Paleontology 6, p. 79-99. 
Ziegler A.M., Raymond A.L., Gierlowski T.C., Horrel M.A., Rowley D.B., Lottes A.L., 1987, Coal, climate and terrestrial productivity: the Present and early Cretaceous compared, in Scott A.C., (Ed.), Coal and Coal-Bearing Strata: Recent Advances: Geological Society of London, Special Publication 32, p. 21-50. 